Argonne National Laboratory

9700 South Cass Avenue

Argonne, Illinois 60439

Edmund A. Huff and Doris R. Huff

Analytical Chemistry Laboratory

Chemical Technology Division

May 1992 


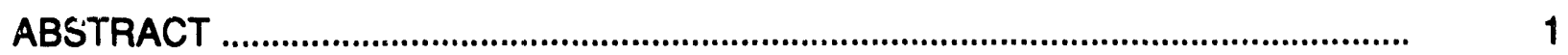

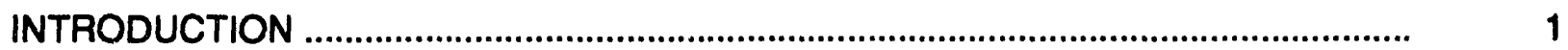

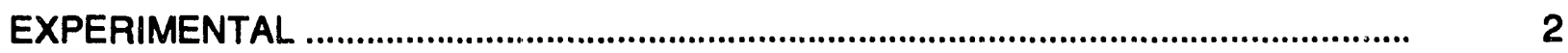

RESULTS AND DISCUSSION

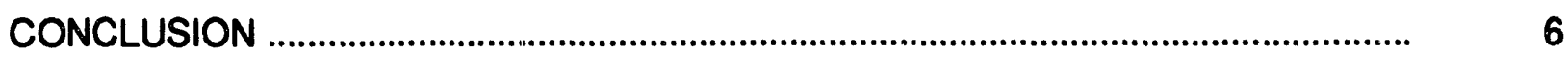

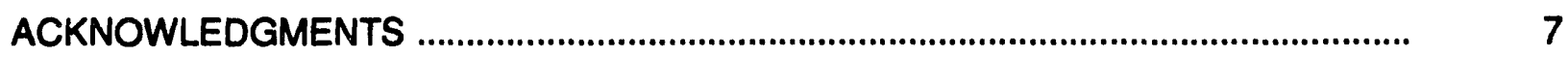

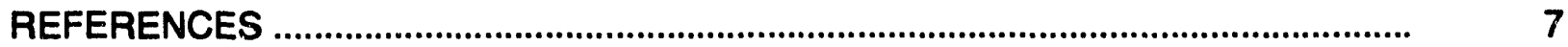




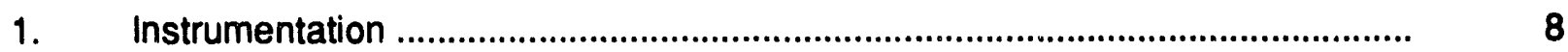

2. Operating Conditions …........................................................................ 9

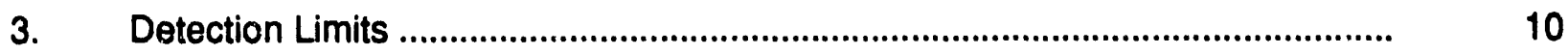

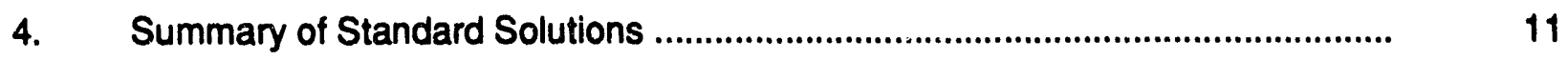

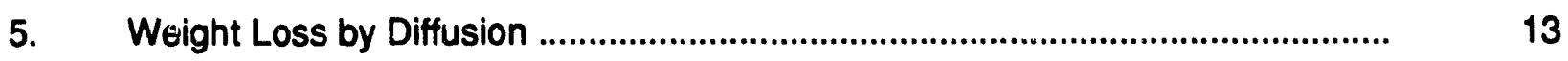

6. Signal-to-Background Ratio vs. Acidity ....................................................... 14

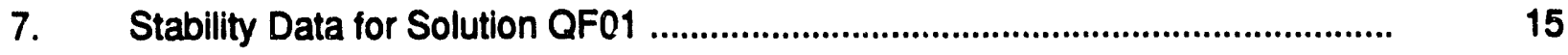

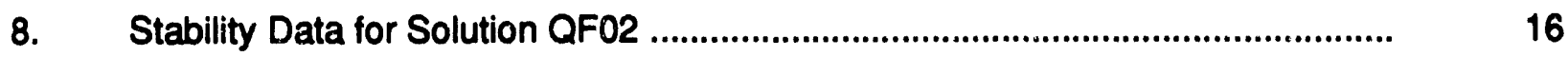

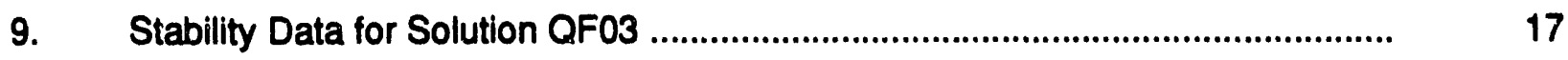

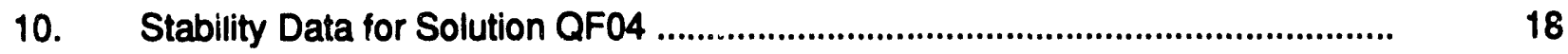

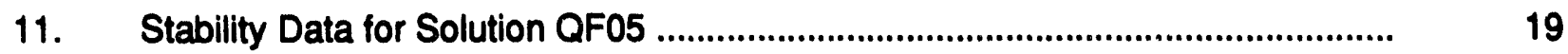

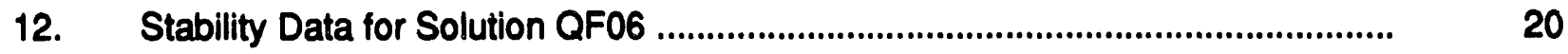

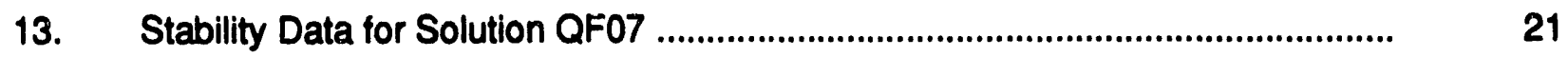

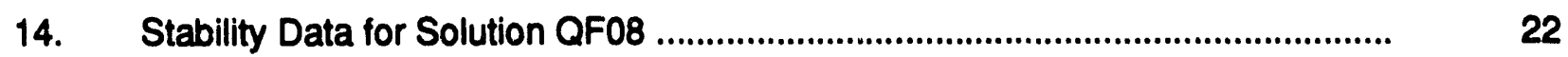

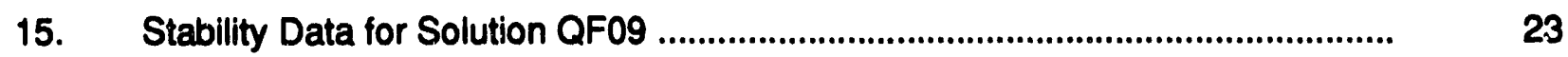

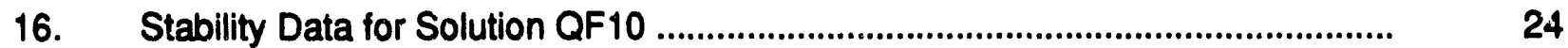

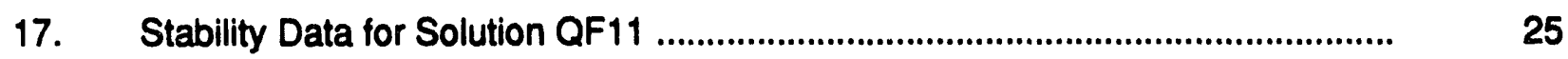

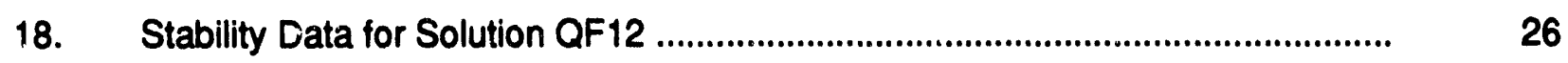

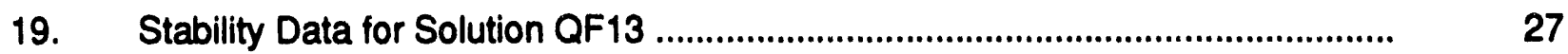


20. Stability Data for Solution QF14 ................................................................... 28

21. Stability Data for Solution QF15 .................................................................... 29

22. Stability Data for Solution QF16 ...................................................................... 30

23. Stability Data for Solution QF17 ..................................................................... 31

24. Stability Data for Solution QF18 ………………….......................................... 32

25. Stability Data for Solution QF19 ..................................................................

26. Stability Data for Solution QF20 .................................................................... 34

27. Stability Data for Solution QF21 ......................................................................... 35

28. Stability Data for Solution QF22 ...................................................................... 36

29. Stability Data for Solution QF23 .......................................................................

30. Stability Data for Solution QF24 …………….................................................. 38

31. Stability Data for Solution Q101 ............................................................................ 39

32. Stability Data for Solution Q102 …...................................................................... 40

33. Stability Data for Silver Solutions ..........................................................................

34. Stability Data for Tin Solutions .....................................................................

35. Stability Data for Solutions QSi ..........................................................................

36. Stability Data for Solutions QAs ......................................................................... 44

37. Stability Data for Niobium Solutions ................................................................... 45

38. Stability Data for Tungsten Solutions .................................................................. 45 


\section{LIST OF FIGURES}

No.

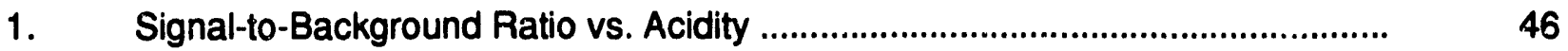

2. Relative Standard Deviation for Aluminum..................................................

3. Relative Standard Deviation for Beryllium ................................................ 47

4. Relative Standard Deviation for Chromium ............................................... 48

5. Relative Standard Deviation for Nickel ................................................. 48

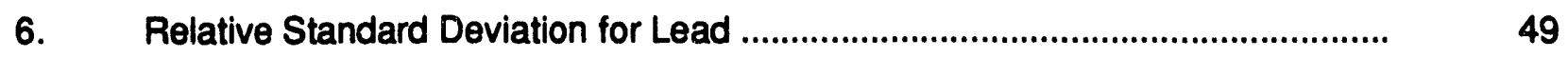

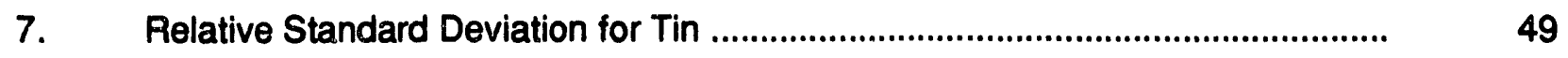




\title{
THE STABILITY OF CALIBRATION STANDARDS FOR \\ ICPIAES ANALYSIS: SIX-MONTH STUDY
}

by

Edmund A. Huff and Doris R. Huff

\begin{abstract}
The stability of instrument calibration standards for Inductively Coupled Plasma/Atomic Emission Spectrometric (ICP/AES) analysis was studied over a six-month period. Data were obtained as functions of analyte concentration, acid type, and acidity. The impact of acid concentration on signal-to-background ratios $(\mathrm{S} / \mathrm{B})$ was also assessed. The results show that analytes maintain their integrity over extended periods with appropriate inorganic acid preservatives. Thus, frequent standard preparations become unnecessary to obtain valid analytical data.

\section{INTRODUCTION}

Inductively Coupled Plasma/Atomic Emission Spectrometry (ICP/AES) is used extensively in the Analytical Chemistry Laboratory $(A C L)$ to characterize diverse analytical samples. This method simultaneously measures the concentrations of multiple cations in solutions. The working standards used for instrument calibration are generally in the 5-20 $\mu \mathrm{g} / \mathrm{mL}$ range. They are prepared from certified single or multielement stock solutions by serial dilution and are preserved with inorganic acids. The accuracy and precision of analytical measurements are greatly affected by uncertainties in standard stabilities as functions of preservative type, analyte content, and acid concentration. As a consequence, a systematic study was initiated to assess the effect of these parameters on data quality, standard procurement needs, and waste minimization.
\end{abstract}




\section{EXPERIMENTAL}

\section{Apparatus}

The ICP/AES measurements were performed on a spectrometer system that incorporated a 48-channel polychromator and a computer-controlled scanning monochromator (Instruments S.A., Inc., Edison, N.J.). Both instruments were focused on a single plasma excitation source. Table 1 lists the instrumentation and Table 2 details the operating conditions for this study. Typical experimental detection limits (DLs) and their corresponding wavelengths are given in Table 3.

\section{Reagents}

Acids. Instra-Analyzed $\mathrm{HCl}$ and $\mathrm{HNO}_{3}$ (Baker Chemical Co.) were used in blank and standard preparations. Water for dilutions $(\geq 18$ Mohm-cm) was obtained from a Sybron/Barnstead ion exchange system.

Standards. Certified standard stock solutions were purchased from the National Institute of Standards and Technology (NIST), SPEX Industries, and Baker Chemical Co. Test solutions and calibration standards were prepared by making serial dilutions of the concentrates and adjusting to the appropriate acidity. This information is summarized in Table 4.

\section{Procedures}

The plasma system was optimized with respect to maximum signal-to-background (S/B) ratios as a function of the vertical viewing aperture. The instrument was calibrated at this position using the two-point calibration procedure with standards and blanks prepared in a $2 \%$ acid $\left(\mathrm{HCl}\right.$ or $\left.\mathrm{HNO}_{3}\right)$ medium. Working standards were prepared on the day of the analytical run and verified against previously used calibration solutions. An agreement of $\pm 3 \%$ for this comparative analysis was considered to provide a valid calibration curve for the subsequent analytical run. 
Since instrument calibration standards were prepared at a single acid concentration ( $2 \%)$, information on the effect of acidity on signal intensity was needed for data assessment of the diverse analytical matrices. As a consequence, $\mathrm{S} / \mathrm{B}$ ratios were determined as a function of $\mathrm{HCl}$ concentration, using a $1-\mu \mathrm{g} / \mathrm{mL}$ multielement standard and a corresponding blank.

The stability of standards is also affected by the possible loss of analyte by a diffusion and/or evaporation mechanism through plastic containers. Since stock and working standards are stored in polyethylene bottles, the diffusion effect was studied by weight-loss measurements from high-density polyethylene (HDPE) and Teflon containers. Bottles were filled with acid solutions, and the chiange in weight as a function of time was established gravimetrically.

\section{RESULTS AND DISCUSSION}

\section{Diffusion}

Table 5 summarizes solution loss data by a diffusion mechanism as a function of time at normally used acid concentrations for ICP/AES analysis. These losses are essentially linear with time and are functions of container type and acid preservative. Solutions with $2 \% \mathrm{HNO}_{3}$ maintained their weight best in HDPE, while those in Teflon showed the lowest weight loss from $\mathrm{HCl}-\mathrm{HNO}_{3}$ mixtures. Although vaporization losses from repeated sampling of bottles and diffusion effects from partially filled containers were not studied, the data suggest that within the accuracy range of ICP/AES (1-10\%), changes via these mechanisms would be in an acceptable range for valid analytical data.

\section{S/B Ratios}

One of the objectives of this investigation was to determine the stability of standards as a function of acidity. The analyte response as a function of this parameter is of interest, since instrument calibration is generally performed at a $2 \%$ acid concentration. Table 6 summarizes 
$\mathrm{S} / \mathrm{B}$ ratios for 18 elements in $\mathrm{HCl}$ solutions. The data show that the presence of mineral acids decreases the emission intensities of atomic and ionic lines for most elements, which is consistent with published results. ${ }^{1}$ It has been postulated that these phenomena are related to the physical state of the plasma at lower acidities $(<1 \underline{M})$ and to the reduced rate of sample uptake at higher acid concentrations (>1M). A few, very sensitive elements (i.e., Be, $\mathrm{Ca}, \mathrm{Mg}$, and $\mathrm{Sr}$ ) exhibit an increase in $\mathrm{S} / \mathrm{B}$ ratios, an observation inconsistent with the above mechanism. Representative data for other elements are plotted in Figure 1 and tend to suggest a linear decrease in the $S / B$ ratio as a function of acidity. These results show that for best accuracy, calibration standards and blanks shcild be matched with respect to acid concentration. Furthermore, for the purpose of this study, only relative analyte changes should be considered in stability assessments, since instrument calibration was performed at a single acid concentration.

\section{Stability Data}

Tables 7 through 30 summarize stability results for 18 elements as a function of acid type, acidity, and analyte concentration. Short- (two months), intermediate- (four months), and overall-term (six months) concentration data and their standard deviations (SD) are provided. In addition, relative standard deviations (RSDs) were calculated and are listed for the study period. In general, all analytes are stable for six months irrespective of preservative $(\mathrm{HCl}$, $\mathrm{HNO}_{3}$ ) or cation concentration. As expected, deviations from the mean decrease with increasing element content, consistent with favorable statistics at higher signal intensities. At low analyte concentration $(0.2 \mu \mathrm{g} / \mathrm{mL})$, elements with relatively high DLs have RSDs exceeding $10 \%$, a result that can be reconciled with greater signal fluctuations. The unexpected stability of $\mathrm{Sn}$ in $\mathrm{HNO}_{3}$ solutions can be explained by the presence of $\mathrm{HCl}$ in the stock standard used to prepare the test mixtures. 
Tables 31 and 32 present data on an Instrument Calibration Veritication Standard (ICV) provided by the U.S. EPA for the Contract Laboratr.y Program (CLP). This solution, prepared as directed, is used to assess the performance of the ICP/AES system for the analysis of environmental samples. The results clearly show that this material is stable over at least a six month period, and weekly repreparations are redundant for valid analytical data and are in fact detrimental to the current trend of waste minimization activities. The Ag data are shown as QIC listing in Table 33 for the same solution, with acceptable results.

Table 33 provides a summary on the stability of $\mathrm{Ag}$ at various $\mathrm{HNO}_{3}$ concentrations. All solutions were stable over the study period within the arbitrary $\pm 5 \%$ RSD guidelines. (Deterioration of $\mathrm{Ag}$ standards can usually be related to the introduction of chloride ions during wash-out procedures.)

Table 34 summarizes the results for $\mathrm{Sn}$. The data support the conclusion that an $\mathrm{HCl}$ $\mathrm{HNO}_{3}$ mixture provided the best shelf iife. Standards prepared in $\mathrm{HNO}_{3}$ deteriorated severely within one week, presumably through the precipitation of insoluble stannic acid.

Table 35 collates stability data for $\mathrm{B}, \mathrm{Mo}, \mathrm{Si}$, and $\mathrm{Ti}$ as a function of concentration and acidity. The short-term results are acceptable for all analytes. However, it was noted that the measured Si results were increasing with time, an observation inconsistent with stability expectations. Further examination revealed that the $2 \mathrm{mg} / \mathrm{mL} \mathrm{Si} \mathrm{stock} \mathrm{standard}(2 \% \mathrm{HCl})$, used for the preparation of the calibrating solution, contained a precipitate. Once this condition was corrected, the measured Si values for the test matrices returned to an acceptable range. In retrospect, the stability of Si standards should have been examined in the presence of HF, a medium known to promote complexation reactions and thus avoid precipitation due to hydrolysis.

The As, Sb, and Se stability data are tabulated in Table 36. The As and Se results are acceptable under the listed experimental conditions. However, like the Si data, the Sb results, 
while having good precision in the short-term domain, exhibit an increase in concentration with time. The instability of the $\mathrm{Sb}$ stock solution $(2 \% \mathrm{HCl})$ was the source of this discrepancy; the test sclution values returned to the acceptance range once a fresh starting standard was prepared.

Tables 37 and 38 present $\mathrm{Nb}$ and $\mathrm{W}$ data, respectively, as a function of element concent ation and preservative. The results verify that $H F$ is required to stabilize these elements in calibration standards to ensure longer shelf-lives.

Figures 2 through 7 graphically summarize experimental RSDs of standards as a function of analyte concentration for selected ulements over the six-month study period. The data show that for elements with relatively high $\mathrm{DLs}(\mathrm{Al}, \mathrm{Pb}, \mathrm{Sn})$, the variability at low concentrations $(0.2$ $\mu \mathrm{g} / \mathrm{mL}$ ) is relatively high (10-20\%), a result expected at the low signal intensities. The reproducibility improves (2-3\%) as the analyte concentration increases. The observed anomalous result for $\mathrm{Sn}$ in $1 \% \mathrm{HNO}_{3}$ is due to precipitation in this mediurn. Elements with moderate and low DLs (Be,Cr, Ni) exhibit a reasonably constant RSD (2\%) over the concentration range studied, an observation consistent with expected fluctuations of relatively high signal intensities.

\section{CONCLUSION}

The results on the stability of calibration standards for ICP/AES analysis show that a suitable acid preservative enables analyte solutions $(5-20 \mu \mathrm{g} / \mathrm{mL})$ to maintain their integrity over at least a six-month period. For the wide range of elements studied, a mixture of $5 \% \mathrm{HCl}+1 \%$ $\mathrm{HNO}_{3}$ appears to provide the best compromise for acceptable shelf lives for most cations. However, for those situations where the relatively high acidities are impractical or undesirable, $2 \% \mathrm{HCl}$ or $2 \% \mathrm{HNO}_{3}$ stabilizes analytes satisfactorily, provided any chemical incompatibilities (i.e., precipitation, hydrolysis) are resolved. 
The variations in S/B ratics as a function of acidity mandate that for best accuracy and precision, salibration standards and blanks should be matrix-matched (i.e., same acid type and concentration, same major constituents). However, for analytical data normally reported in the accuracy range of $3-10 \%$, approximate acid concentrations are sufficient for satisfactory results.

Changes in analyte concentrations due to evaporation and diffusion through plastic containers do not appear to make a significant contribution to inaccuracies, compared to the more pronounced effects introduced by the excitation and sample transport system. However, partially filled bottles, increased frequency of sampling, and environmental storage conditions could have a considerably larger impact on standard stabilities than those observed in this study.

This study clearly shows that the frequency of calibration standard preparations could be lowered significantly for ICP/AES analyses at moderate accuracies (3-10\%). As a consequence, benefits in lower costs for standard preparation and waste disposal would be realized, in addition to better allocation of analytical effort.

\section{ACKNOWLEDGMENTS}

The financial support of the Support Development Fund Committee at ANL has made this investigation possible. The development of computer software programs for data compilations and reductions by J. E. Kulaga is gratefully acknowledged.

\section{REFERENCES}

1. J. E. Yoshimura, H. Suzuki, S. Yamazaki, and S. Toda, "Interference by Mineral Acids in Inductively Coupled Plasma Aiomic Emission Spectrometry," Analyst 115, 167 (1990). 


\section{Table 1. Instrumentation}

\section{A. Spectrometers}

Polychromator

Monochromator
Instruments S.A., Inc., Model J-Y48P 1-m Paschen-Runge with 2550 grooves/mm holographic concave grating, 20- $\mu \mathrm{m}$ entrance and $50-\mu \mathrm{m}$ exit slits. Hamamatsu R300 and R306 photumultiplier tubes, 48 channels.

Instruments S. A., Inc., Model J-Y38 1-m Czerny-Turner with SpectraLink controller. 2400 grooves $/ \mathrm{mm}$ holographic plane grating, 50- $\mu \mathrm{m}$ entrance and exit slits; Hamamatsu R955 photomultiplier tube.

\section{B. Power and Nebulizer System}

Generator

Nebulizer

Torch

Spray Chamber
Plasma-Therm Model HFP-2500, 27.12 MHz with 3-turn copper load coil.

Instruments S. A., Inc., concentric with a Pt-Ir capillary tube.

Instruments S. A., Inc., demountable in a Mermet-Trassey configuration.

Instruments S. A., Inc., double-barrel, constructed from Ryton.

\section{Computer System}

\section{Computer}

Terminals

Software
Digital Equipment Corp. PDP-11/73 with $768 \mathrm{~K}$ byte of memory, three RL-02 disks.

Digital Equipment Corp. DEC Writer III hard copy and DEC VT-340 video with graphics.

1. Instruments S. A., Inc .-supplied analytical program run by the $D E C$ RSX-11M operating system.

2. ANL-developed report generation and quality assurance programs. 


\section{Table 2. Operating Conditions}

$\begin{array}{ll}\text { Forward R.F. Power } & 1.10 \mathrm{~kW} \\ \text { Reflected Power } & <5 \mathrm{~W} \\ \text { Argon Flow Rates } & \\ \text { Outer Gas } & 14 \mathrm{~L} / \mathrm{min} \\ \text { Intermediate Gas } & 0.4 \mathrm{~L} / \mathrm{min} \\ \text { Sheath Gas } & 0.5 \mathrm{~L} / \mathrm{min} \\ \text { Nebulizer Gas } & 0.6 \mathrm{~L} / \mathrm{min} \\ \text { Sample Uptake Rate } & 2.8 \mathrm{~mL} / \mathrm{min} \\ \text { Observation Height } & 16 \mathrm{~mm} \text { above load coil } \\ \text { Integration Times } & \\ \text { Polychromator } & 10 \mathrm{sec} \\ \text { Monochromator } & 1 \mathrm{sec}\end{array}$


6

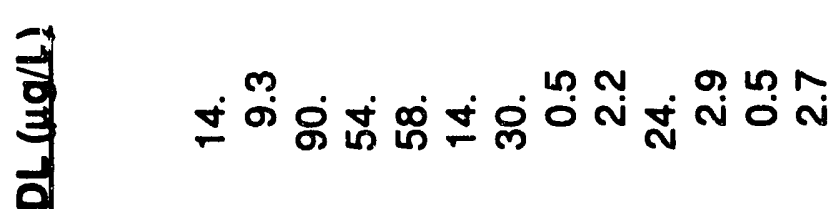
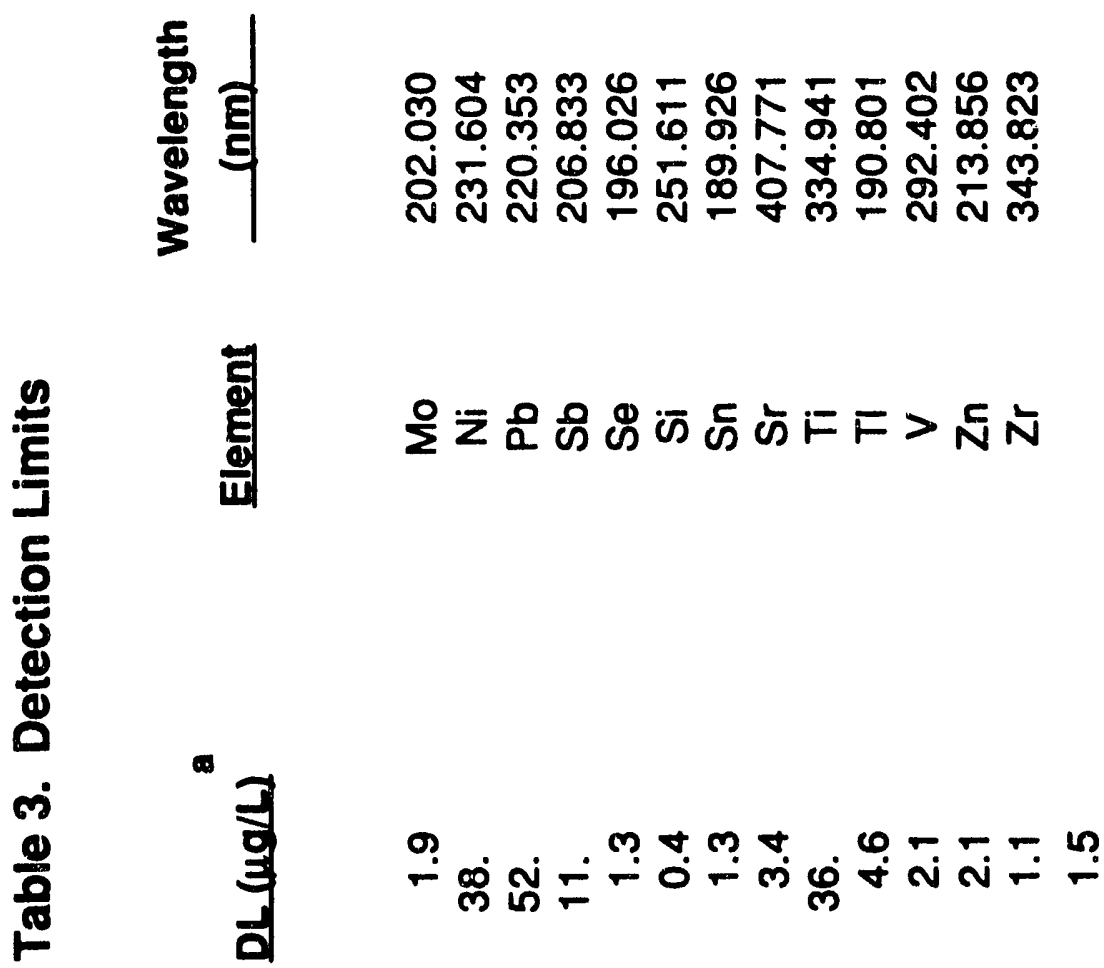

$\underset{\infty}{\infty}$

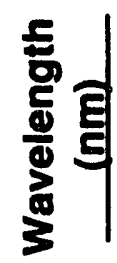

๓

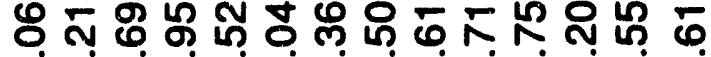

亗

$\infty$

รั่

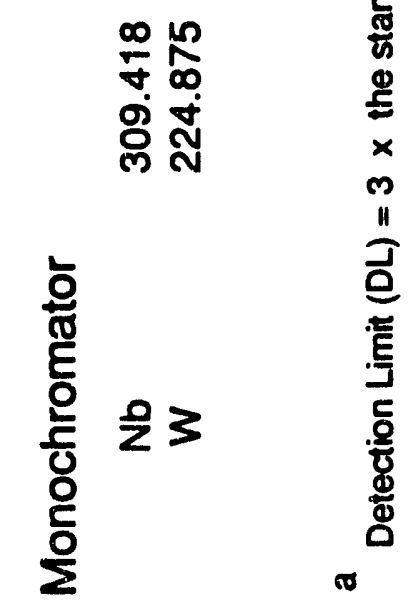

형 현

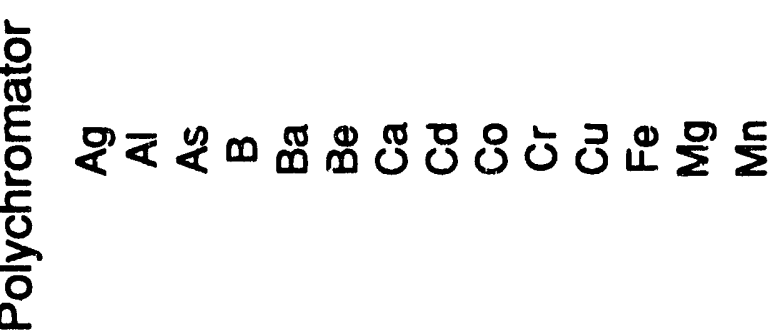




\section{Table 4. Summary of Standard Solutions}

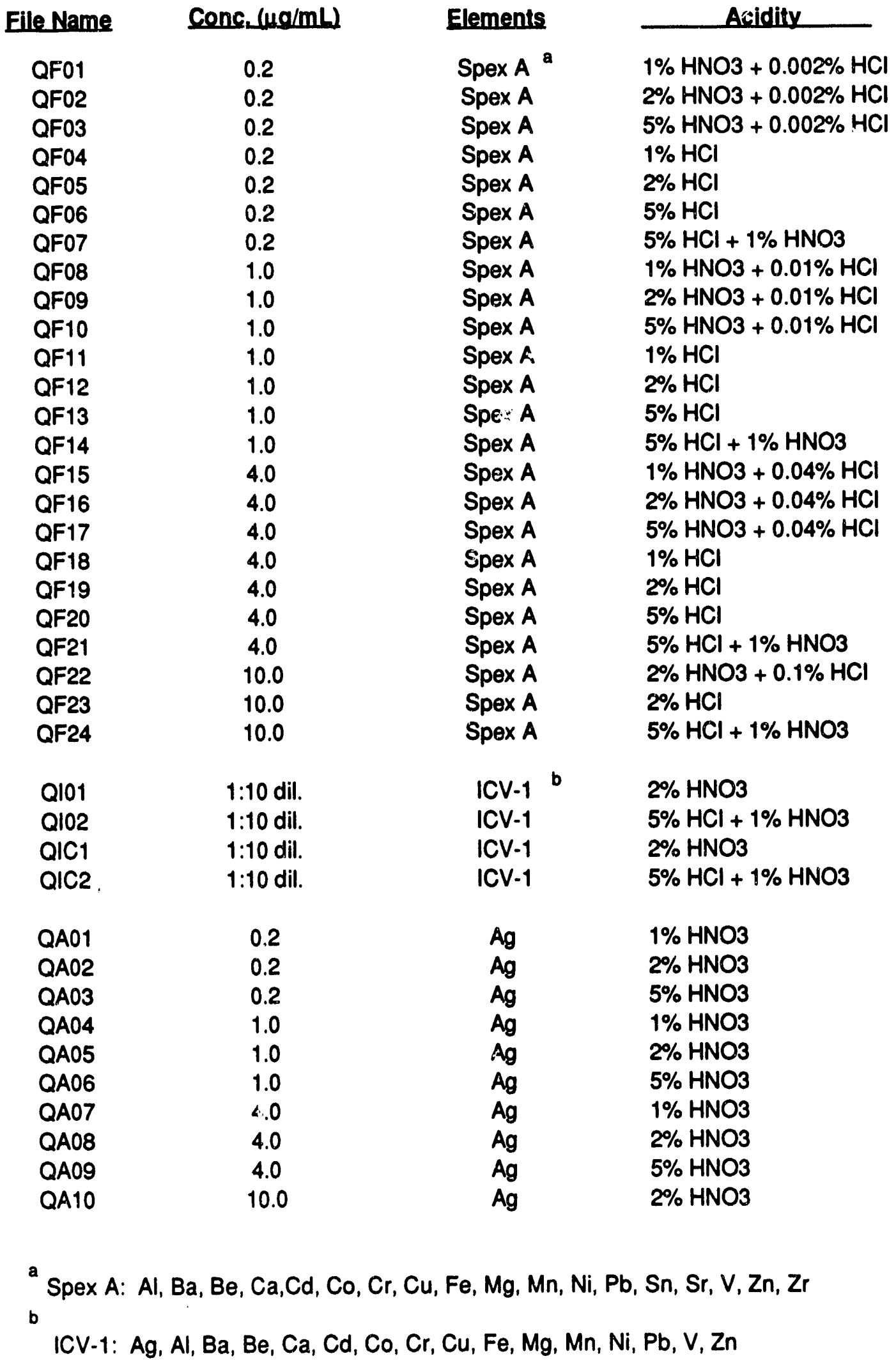




\section{Table 4. Summary of Standard Solutions (contd)}

\begin{tabular}{|c|c|c|c|}
\hline File Name & Conc. $(\mu \mathrm{a} / \mathrm{mL})$ & Elements & Acidity \\
\hline QSi1 & $0.5 ; 1.0$ & B, Mo, Ti; Si & $2 \% \mathrm{HNO}$ \\
\hline QSi2 & $0.5 ; 1.0$ & B, Mo, Ti; Si & $2 \% \mathrm{HCl}$ \\
\hline QSi3 & $0.5 ; 1.0$ & B, Mo, Ti; Si & $5 \% \mathrm{HCl}+1 \% \mathrm{HNO} 3$ \\
\hline QSi4 & $2.5 ; 5.0$ & B, Mo, Ti; Si & $2 \%$ HNO3 \\
\hline QSi5 & $2.5 ; 5.0$ & B, Mo, Ti; Si & $2 \% \mathrm{HCl}$ \\
\hline QSi6 & $2.5 ; 5.0$ & B, Mo, Ti; Si & $5 \% \mathrm{HCl}+1 \% \mathrm{HNO} 3$ \\
\hline QSi7 & $10.0 ; 20.0$ & B, Mo, Ti; Si & $2 \% \mathrm{HNO} 3$ \\
\hline QSi8 & $10.0 ; 20.0$ & B, Mo, Ti; Si & $2 \% \mathrm{HCl}$, \\
\hline QSig & $10.0 ; 20.0$ & B, Mo, Ti; Si & $5 \% \mathrm{HCl}+-1 \% \mathrm{HNO}$ \\
\hline QAs1 & 5.0 & As, $\mathrm{Sb}, \mathrm{Se}$ & $2 \% \mathrm{HNO} 3$ \\
\hline QAs2 & 5.0 & As, $\mathrm{Sb}, \mathrm{Se}$ & $2 \% \mathrm{HCl}$ \\
\hline QAs3 & 5.0 & $\mathrm{As}, \mathrm{Sb}, \mathrm{Se}$ & $5 \% \mathrm{HCl}+1 \% \mathrm{HNO}$ \\
\hline QAs4 & 20.0 & As, $\mathrm{Sb}, \mathrm{Se}$ & $2 \%$ HNO3 \\
\hline QAs5 & 20.0 & As, $\mathrm{Sb}, \mathrm{Se}$ & $2 \% \mathrm{HCl}$ \\
\hline QAs6 & 20.0 & $\mathrm{As}, \mathrm{Sb}, \widehat{\mathrm{Se}}$ & $5 \% \mathrm{HCl}+1 \% \mathrm{HNO} 3$ \\
\hline QSn1 & 5.0 & Sn & $2 \%$ HNO3 \\
\hline QSn2 & 5.0 & Sn & $2 \% \mathrm{HCl}$ \\
\hline QSn3 & 5.0 & Sn & $5 \% \mathrm{HCl}+1 \% \mathrm{HNO} 3$ \\
\hline QSn4 & 20.0 & Sn & $2 \%$ HNO3 \\
\hline QSn5 & 20.0 & Sn & $2 \% \mathrm{HCl}$ \\
\hline QSn6 & 20.0 & Sn & $5 \% \mathrm{HCl}+1 \% \mathrm{HNO}$ \\
\hline QW01 & 1.0 & $w$ & $2 \% \mathrm{HCl}$ \\
\hline QW02 & 1.0 & $w$ & $2 \% \mathrm{HCl}+0.5 \% \mathrm{HF}$ \\
\hline QW03 & 5.0 & $w$ & $2 \% \mathrm{HCl}$ \\
\hline QW04 & 5.0 & W & $2 \% \mathrm{HCl}+0.5 \% \mathrm{HF}$ \\
\hline QW05 & 20.0 & $w$ & $2 \% \mathrm{HCl}$ \\
\hline QW06 & 20.0 & $w$ & $2 \% \mathrm{HCl}+0.5 \% \mathrm{HF}$ \\
\hline QNb1 & 1.0 & $\mathrm{Nb}$ & $2 \% \mathrm{HCl}$ \\
\hline QNb2 & 1.0 & $\mathrm{Nb}$ & $2 \% \mathrm{HCl}+0.5 \% \mathrm{HF}$ \\
\hline QNb3 & 5.0 & $\mathrm{Nb}$ & $2 \% \mathrm{HCl}$ \\
\hline QNb4 & 5.0 & $\mathrm{Nb}$ & $2 \% \mathrm{HCl}+0.5 \% \mathrm{HF}$ \\
\hline QNb5 & 20.0 & $\mathrm{Nb}$ & $2 \% \mathrm{HCl}$ \\
\hline QNb6 & 20.0 & Nb & $2 \% \mathrm{HCl}+0.5 \% \mathrm{HF}$ \\
\hline
\end{tabular}


Table 5. Weight Loss by Diffusion

$\%$ Weight Loss

\begin{tabular}{llccc} 
Material & \multicolumn{1}{c}{ Acid } & 3 months & $\mathbf{6}$ months & $\mathbf{9}$ months \\
HDPE a & $2 \% \mathrm{HNO}^{2}$ & 0.05 & 0.08 & 0.12 \\
HDPE & $2 \% \mathrm{HCl}$ & 0.09 & 0.16 & 0.23 \\
HDPE & $5 \% \mathrm{HCl}+1 \% \mathrm{HNO3}$ & 0.08 & 0.13 & 0.19 \\
& & & & \\
FEP b & $2 \% \mathrm{HNO}$ & 0.18 & 0.29 & 0.42 \\
FEP & $2 \% \mathrm{HCl}$ & 0.07 & 0.12 & 0.17 \\
FEP & $5 \% \mathrm{HCl}+1 \% \mathrm{HNO3}$ & 0.02 & 0.05 & 0.07
\end{tabular}

a HDPE: High-Density Polyethylene

FEP: Fluorinated Ethylene Propylene (Teflon) 


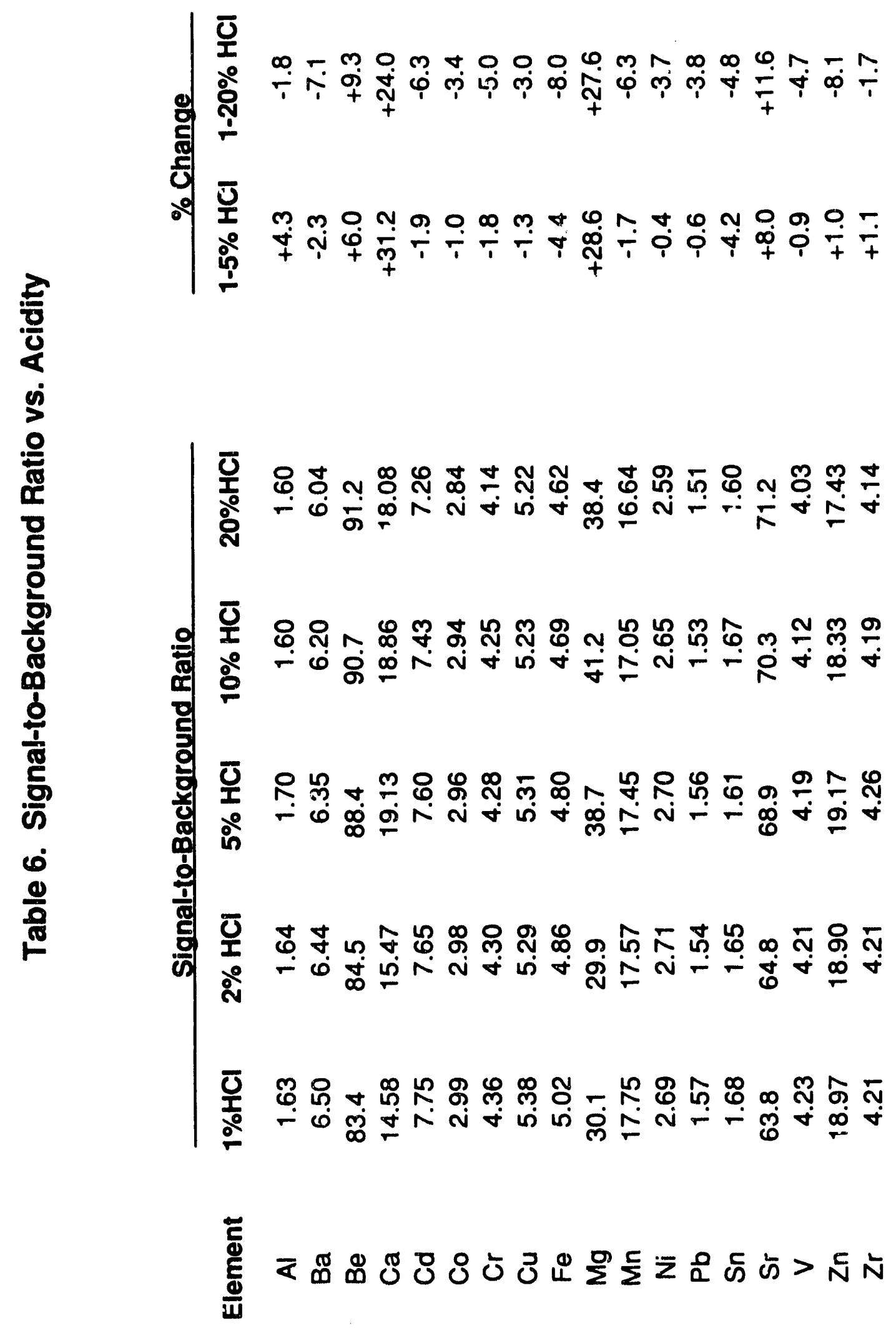




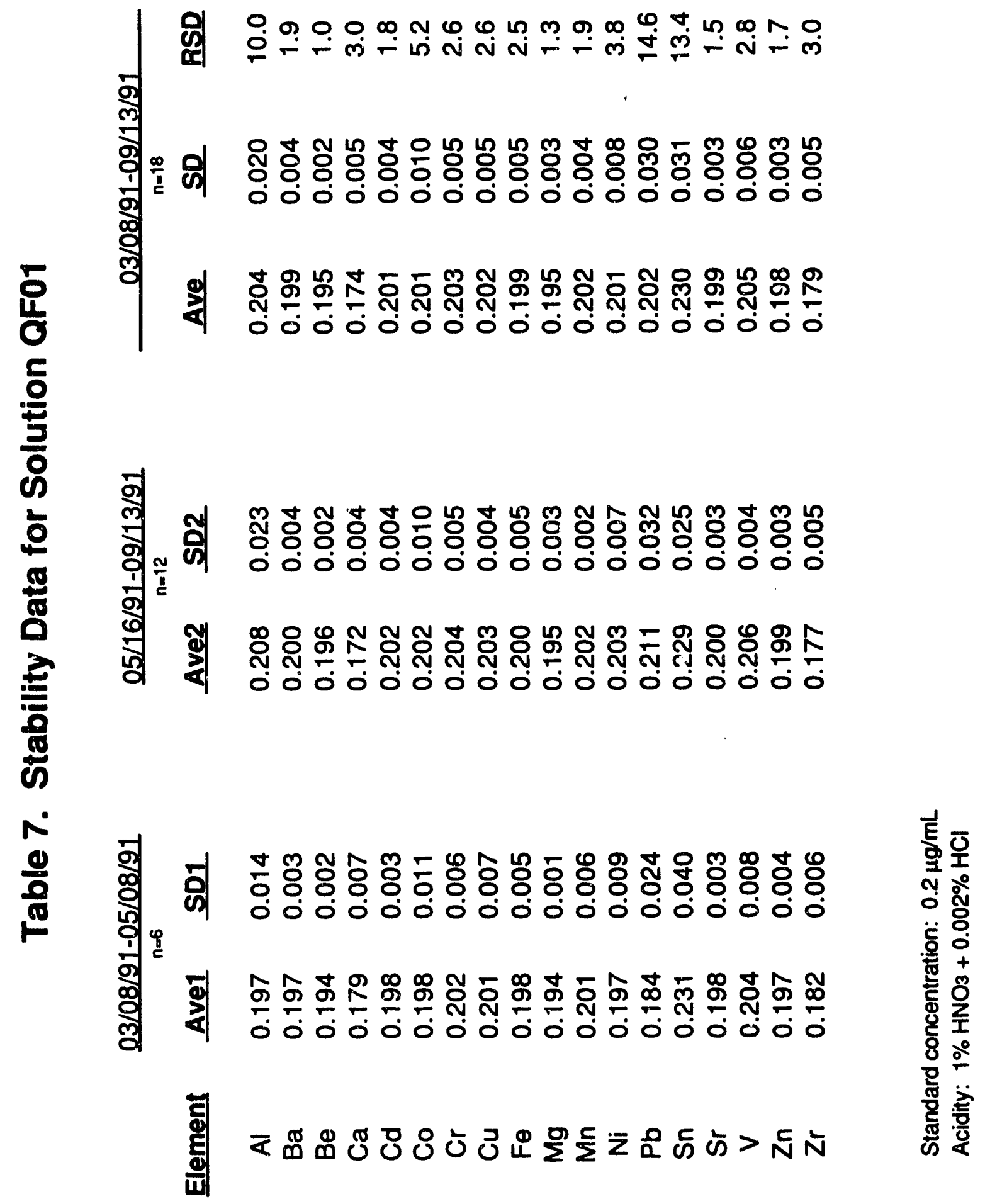




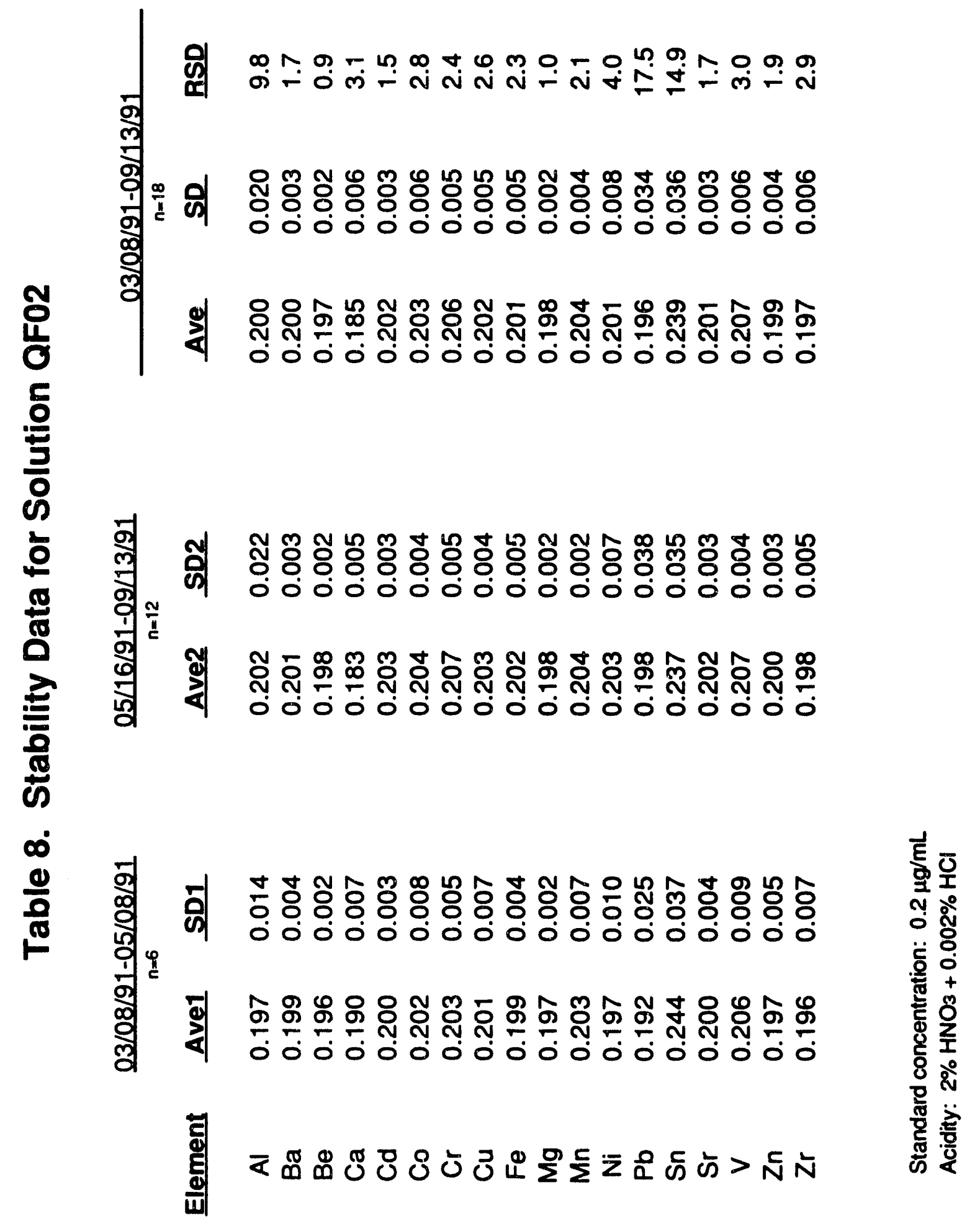




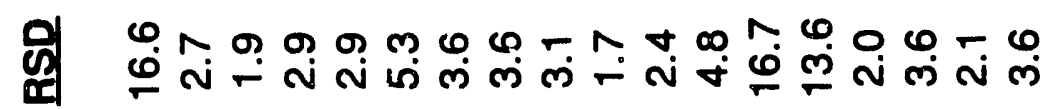

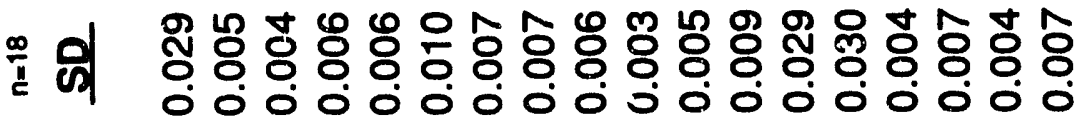

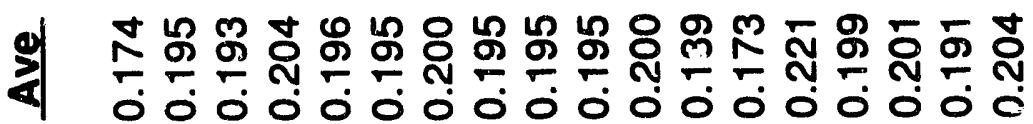

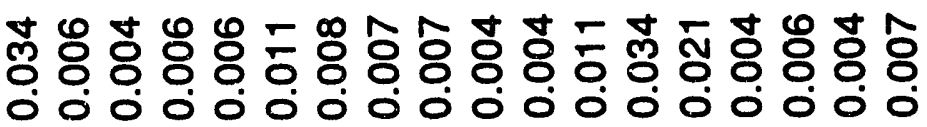

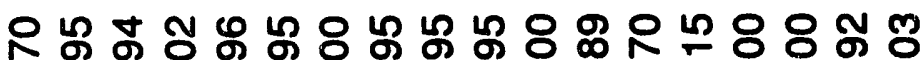

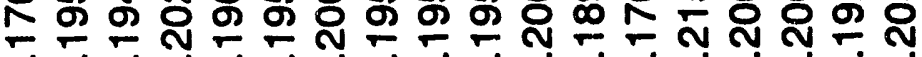
б́ல

क'

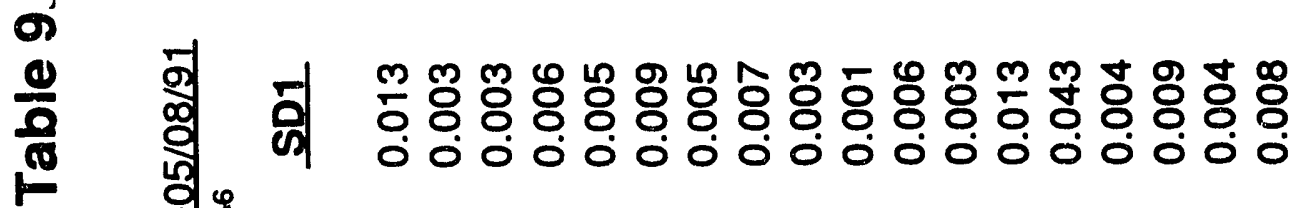

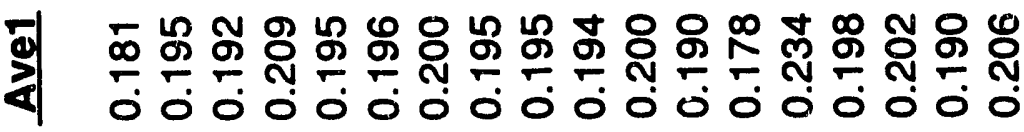




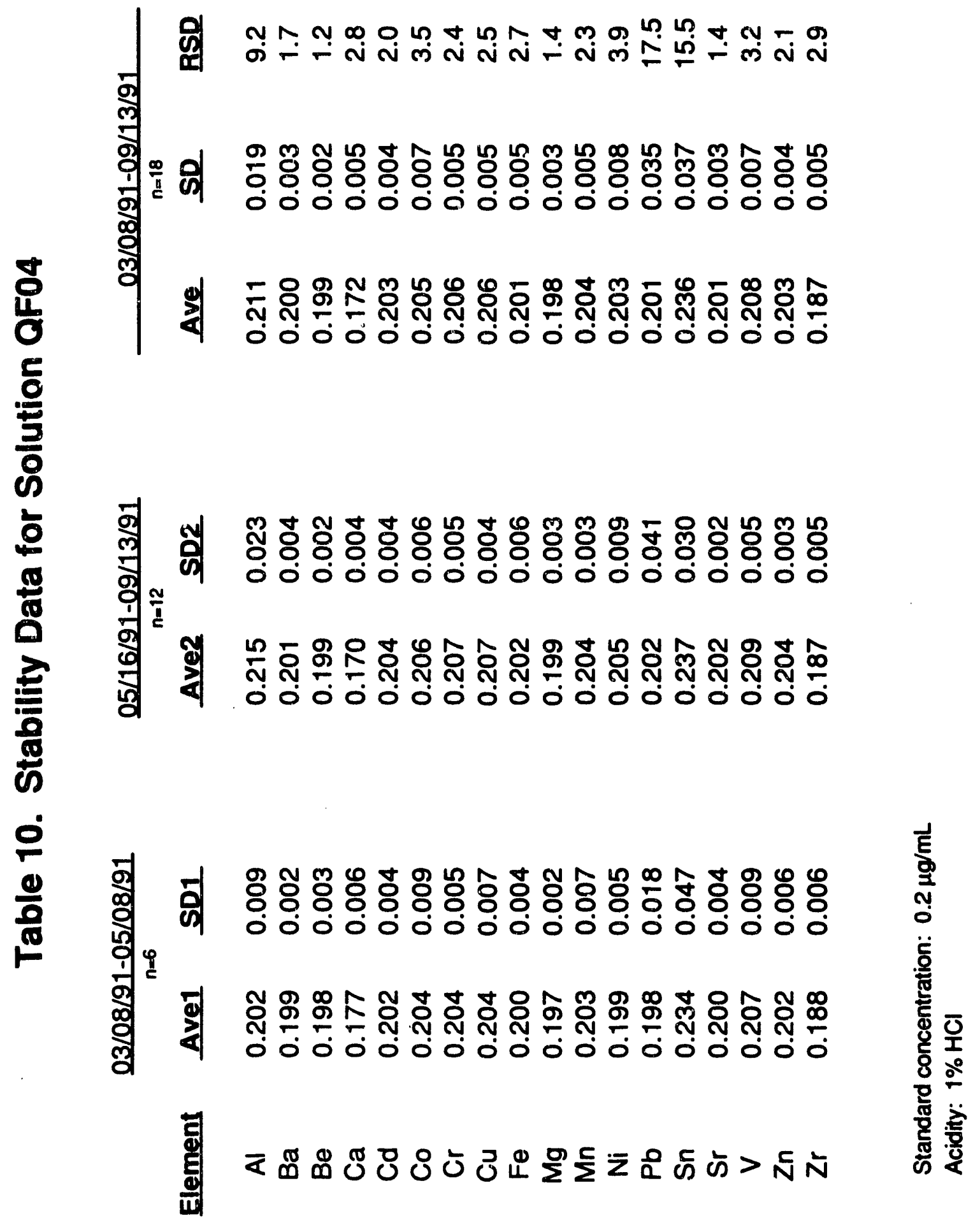




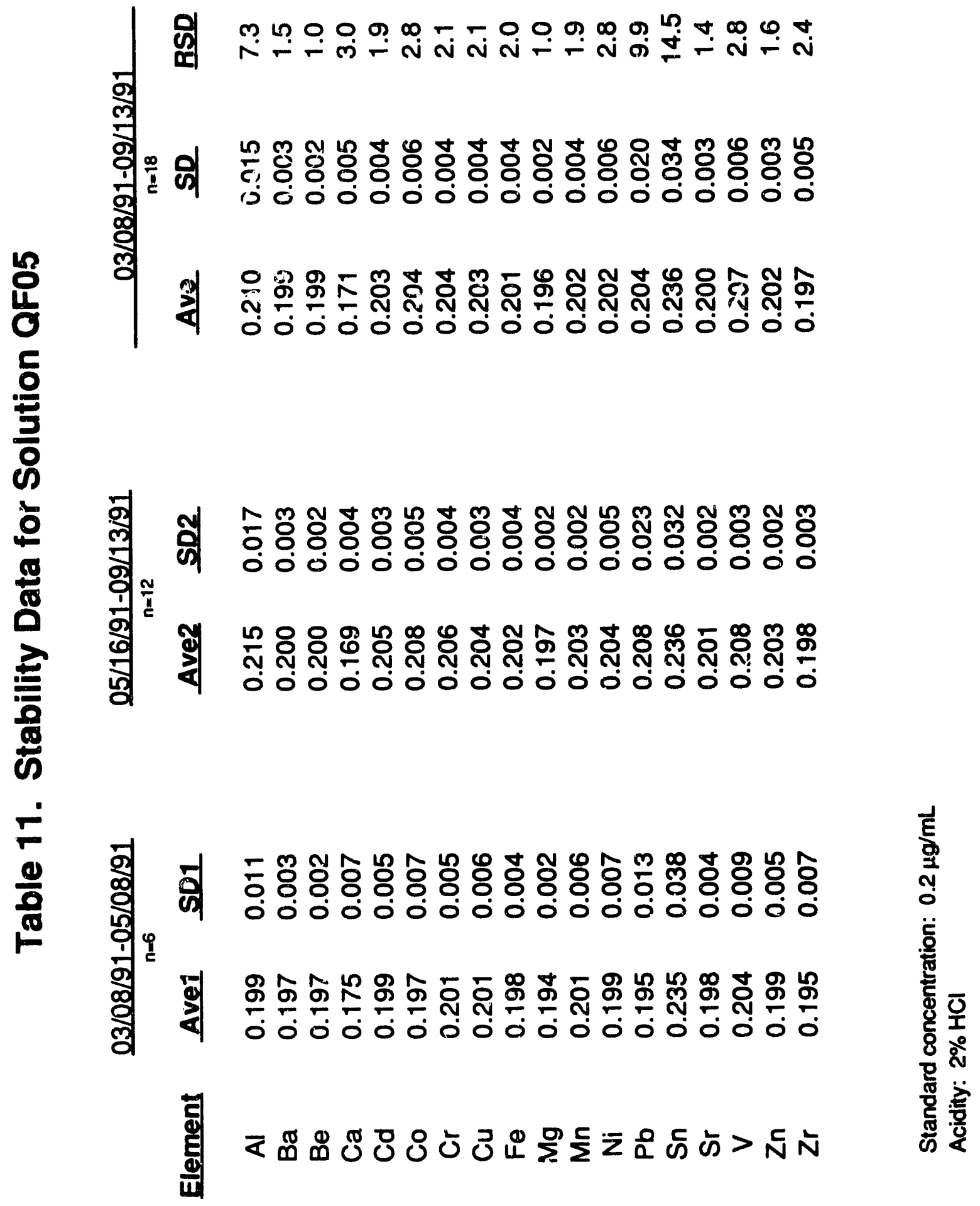




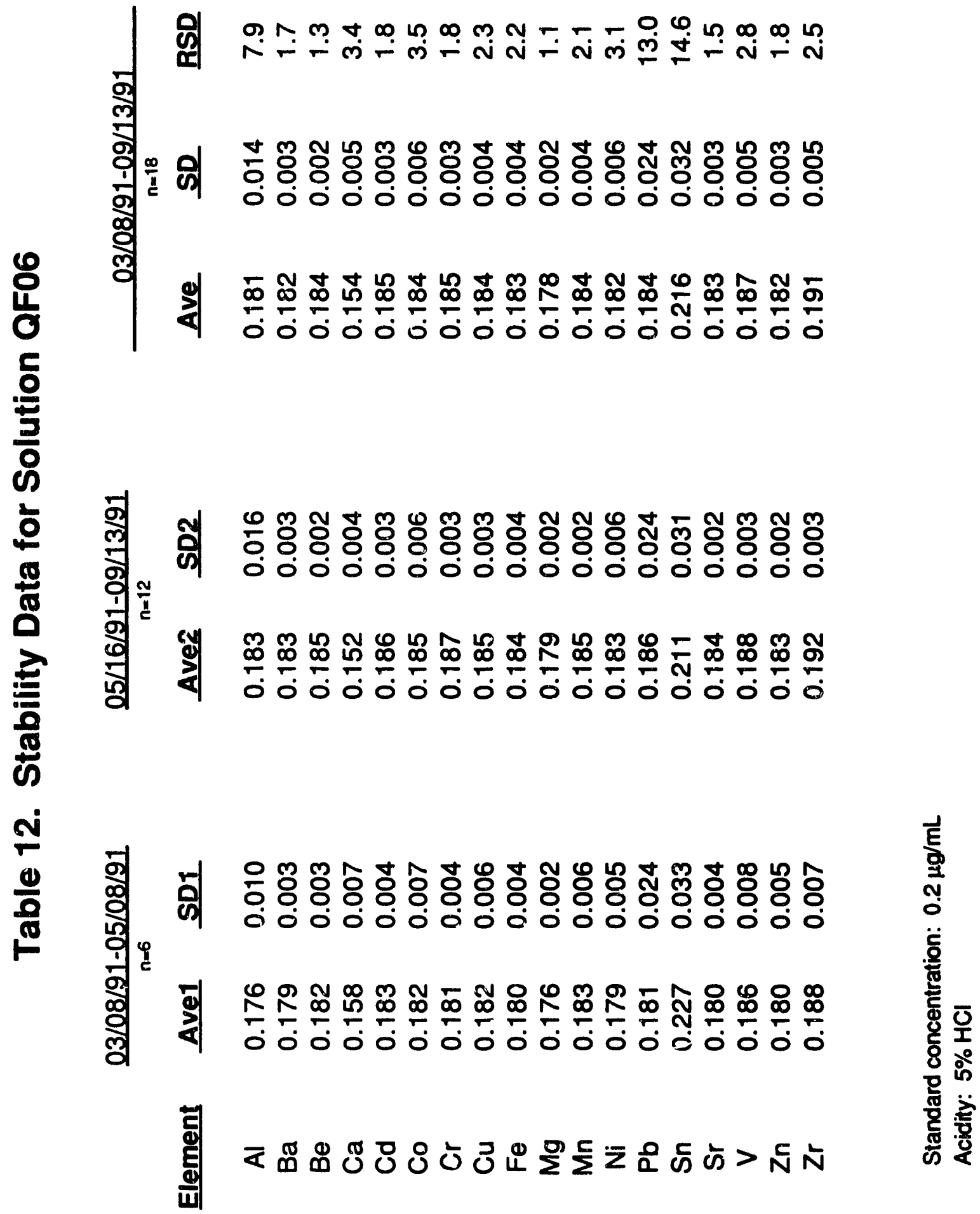




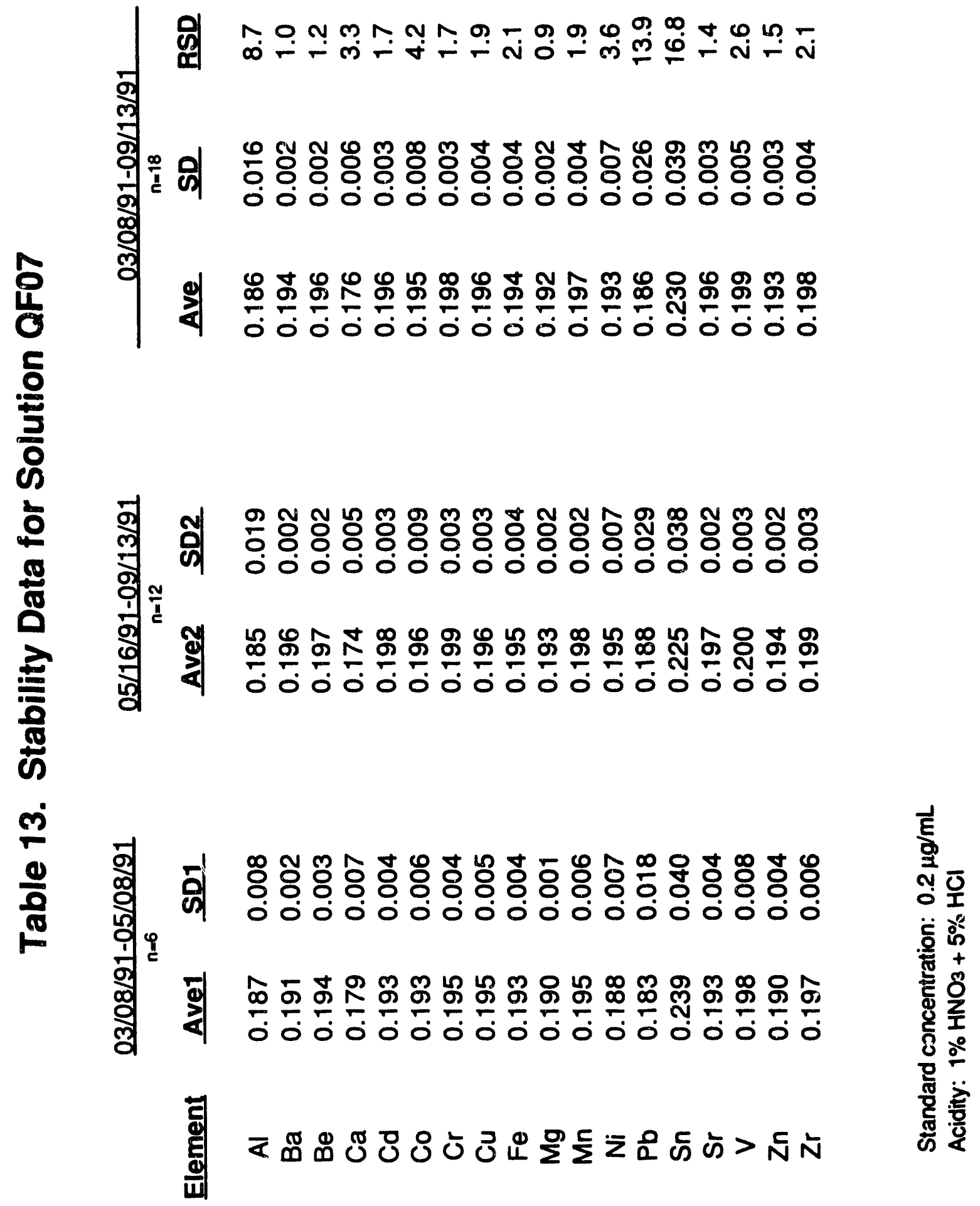




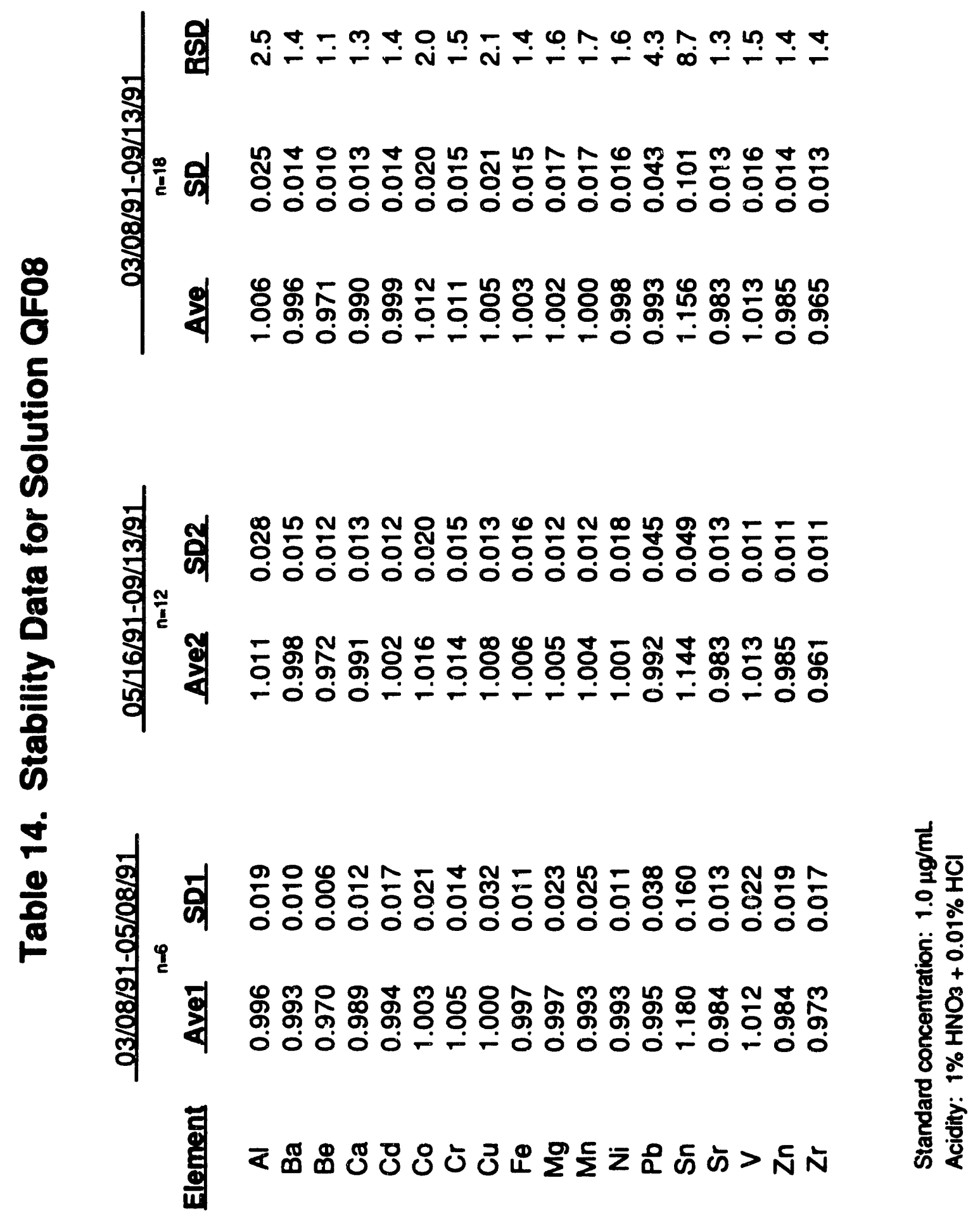




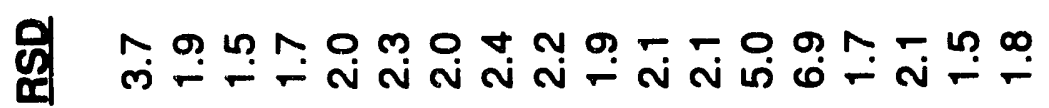

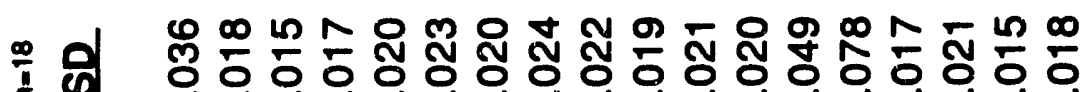

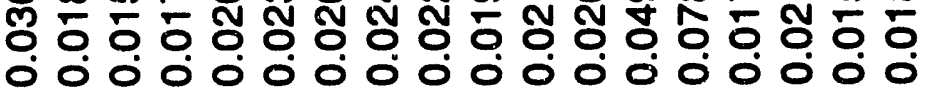

$\frac{8}{0}$

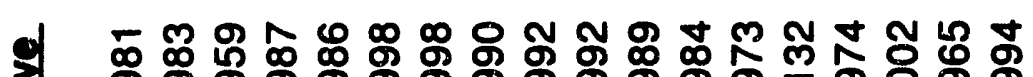

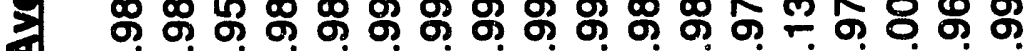

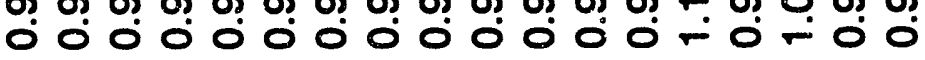

के

อ่

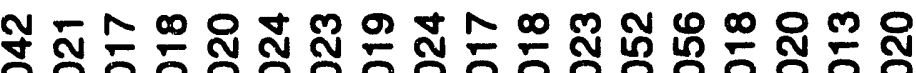

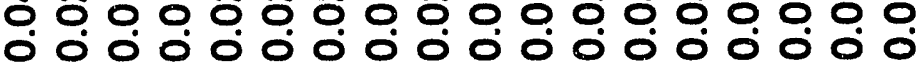

テ \% \% \% \%

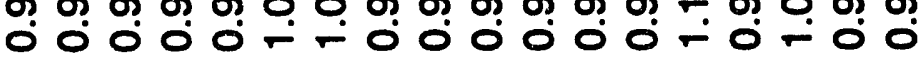

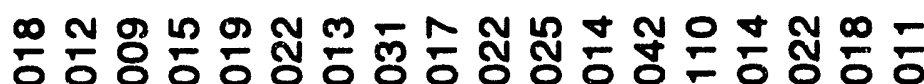

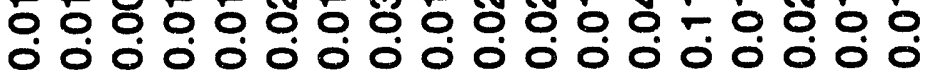

舟

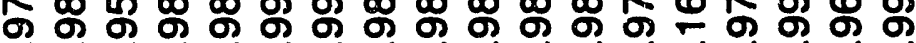
$0000000000000+0000$

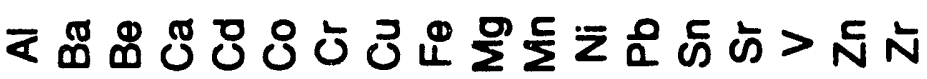




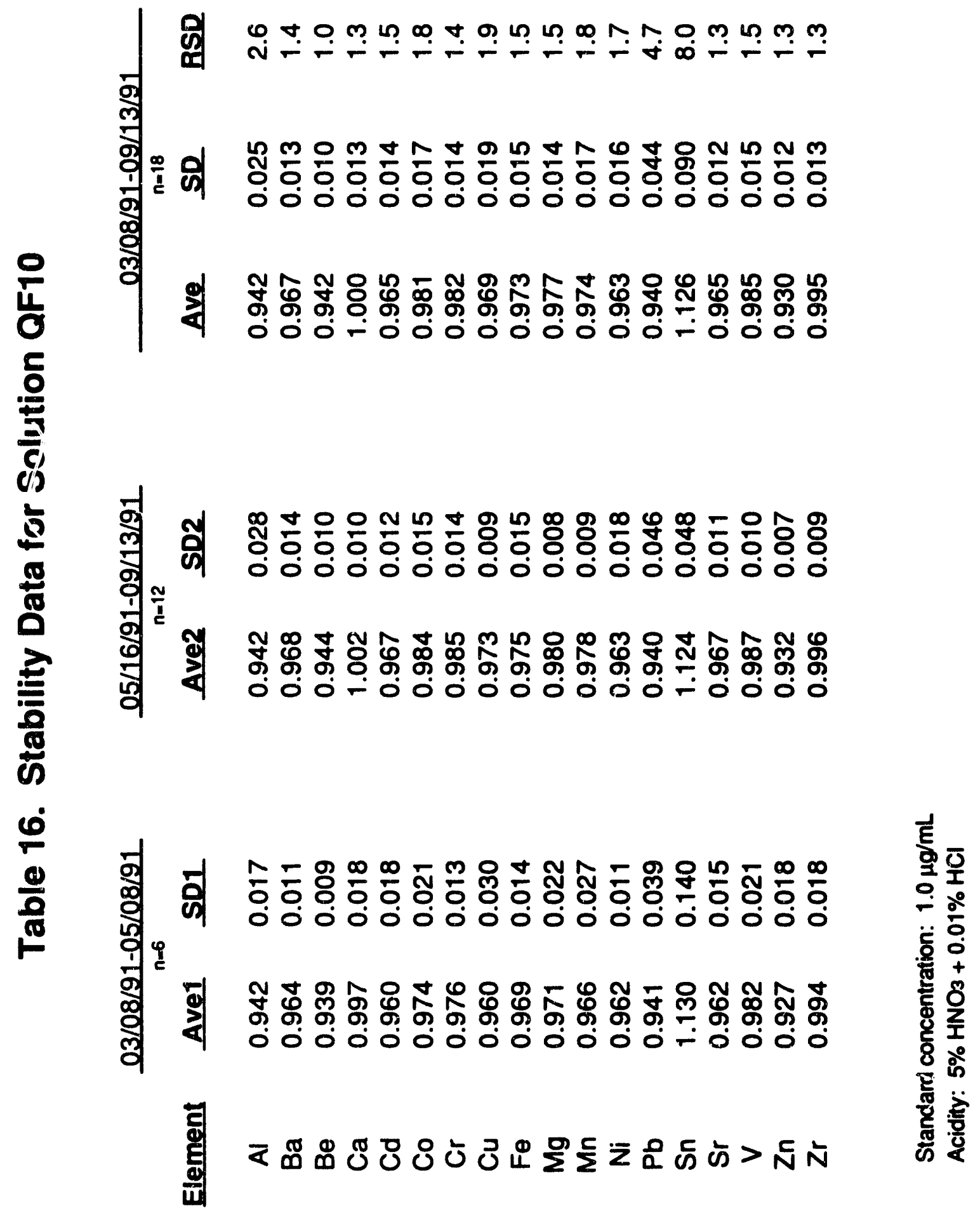




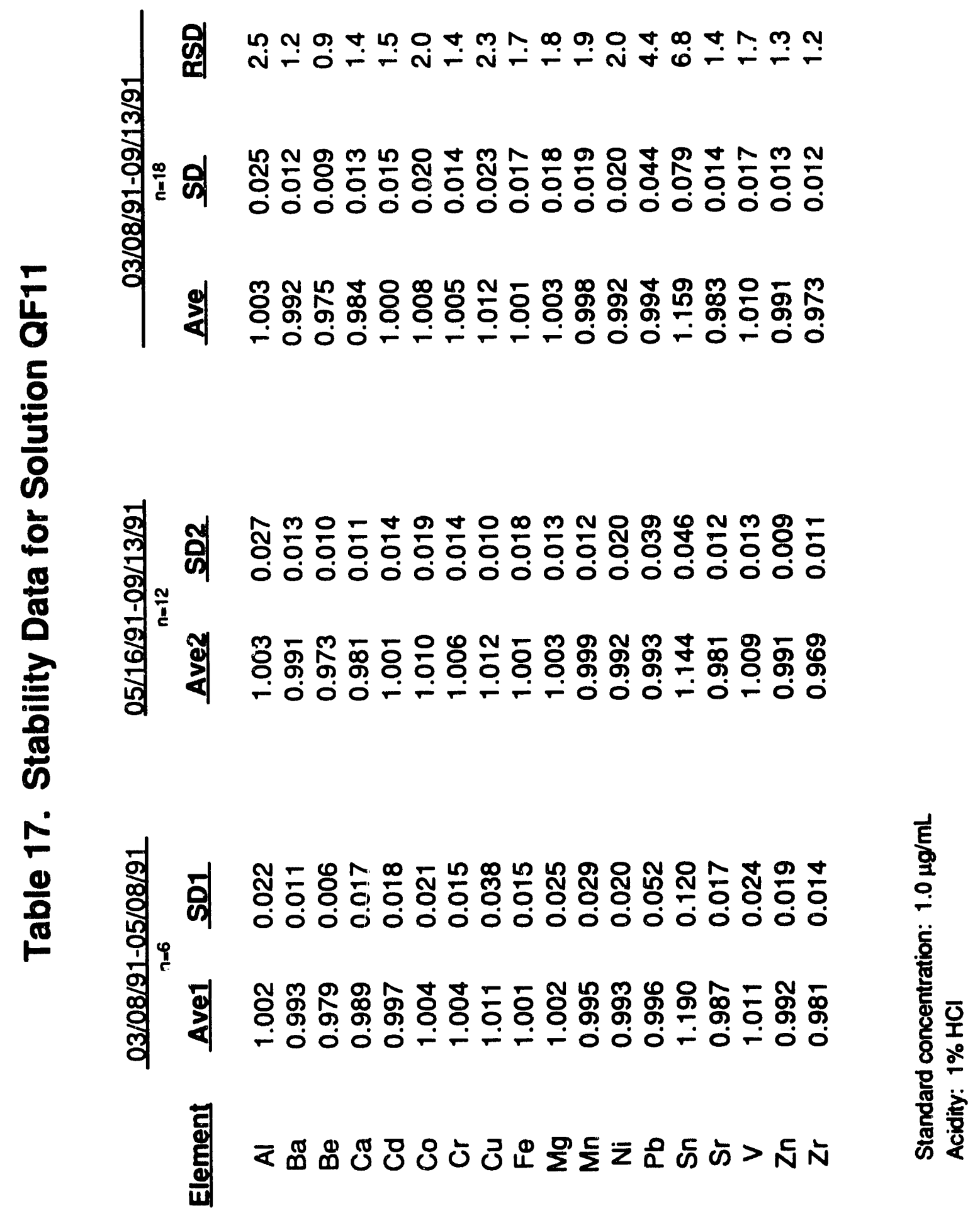




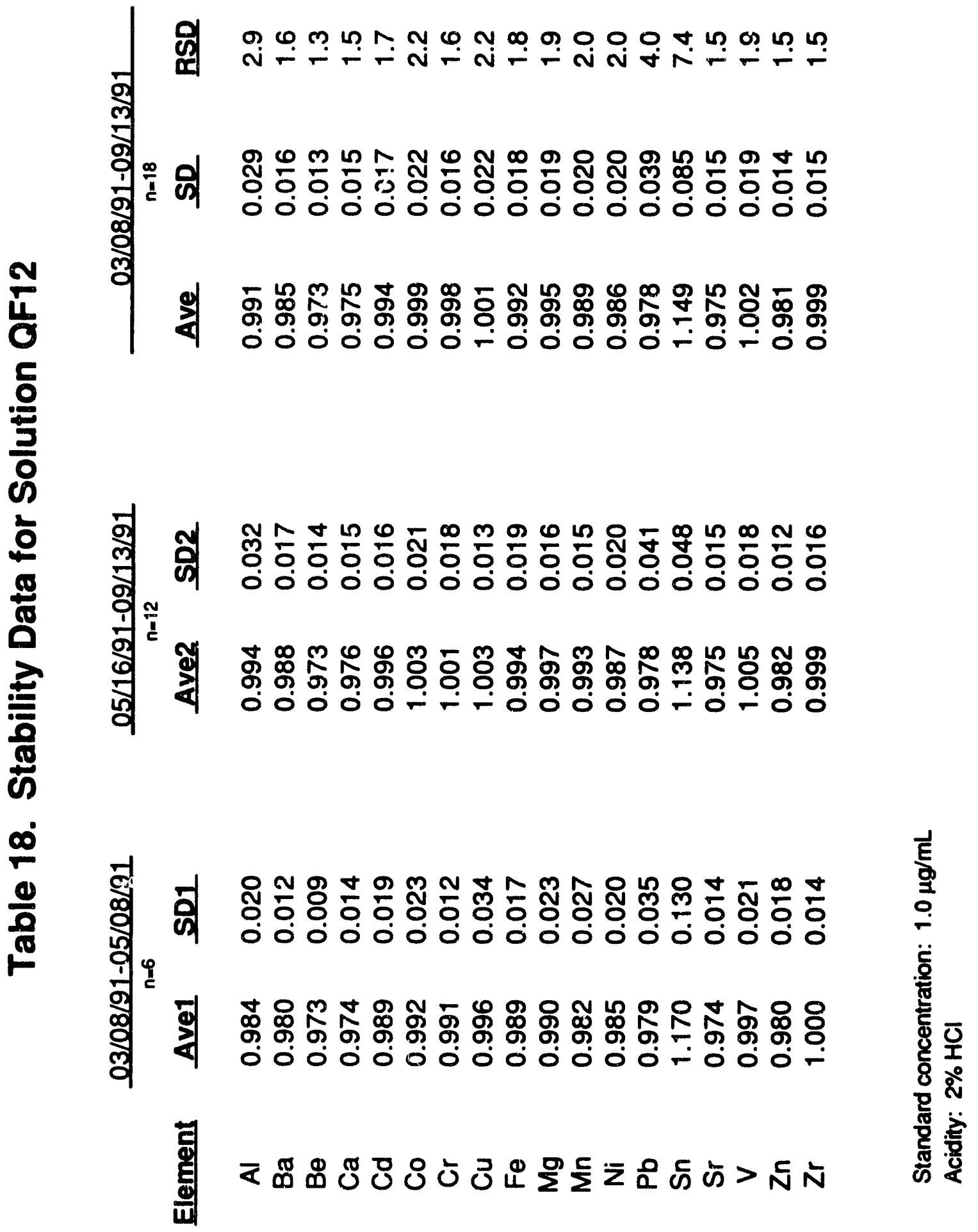




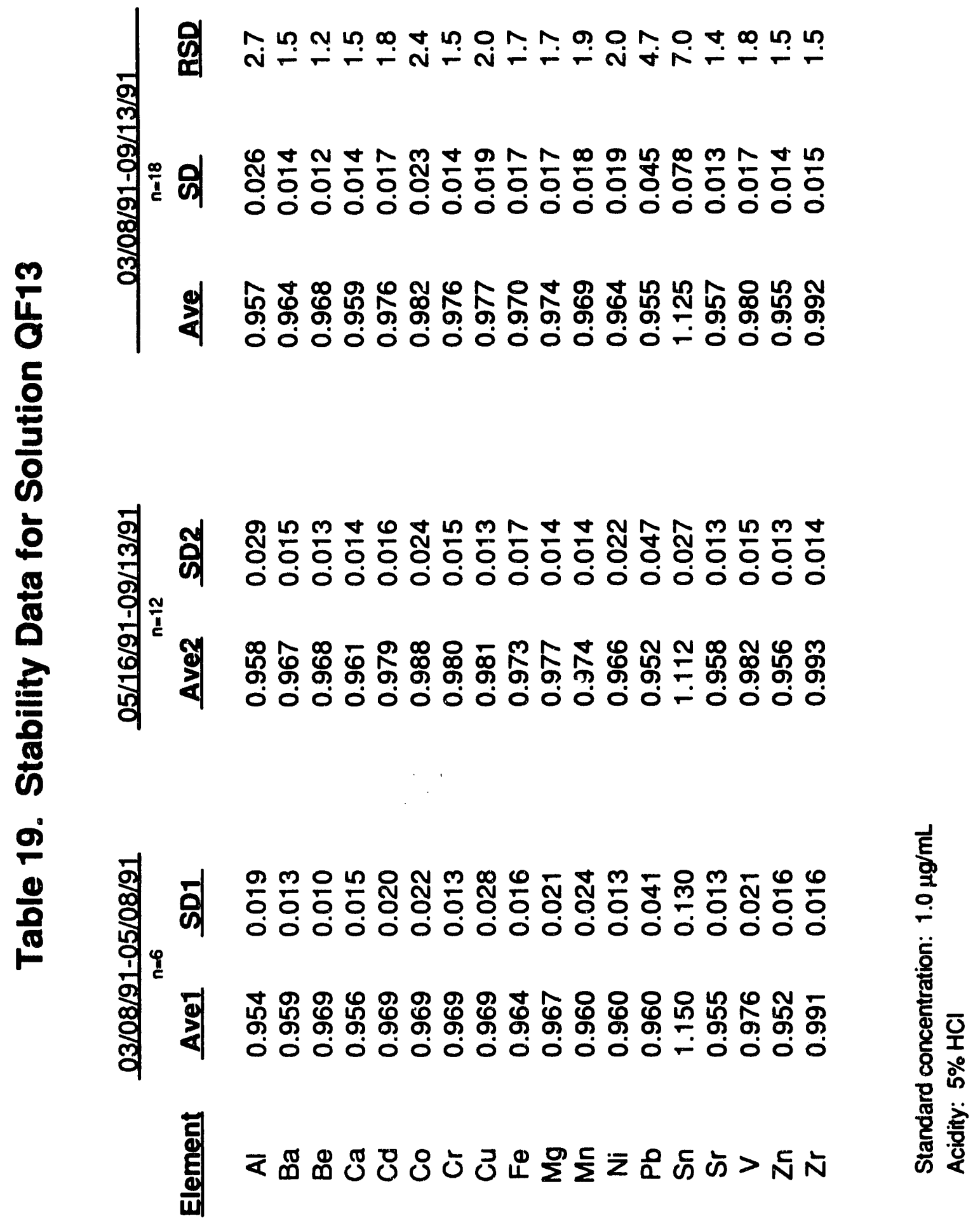




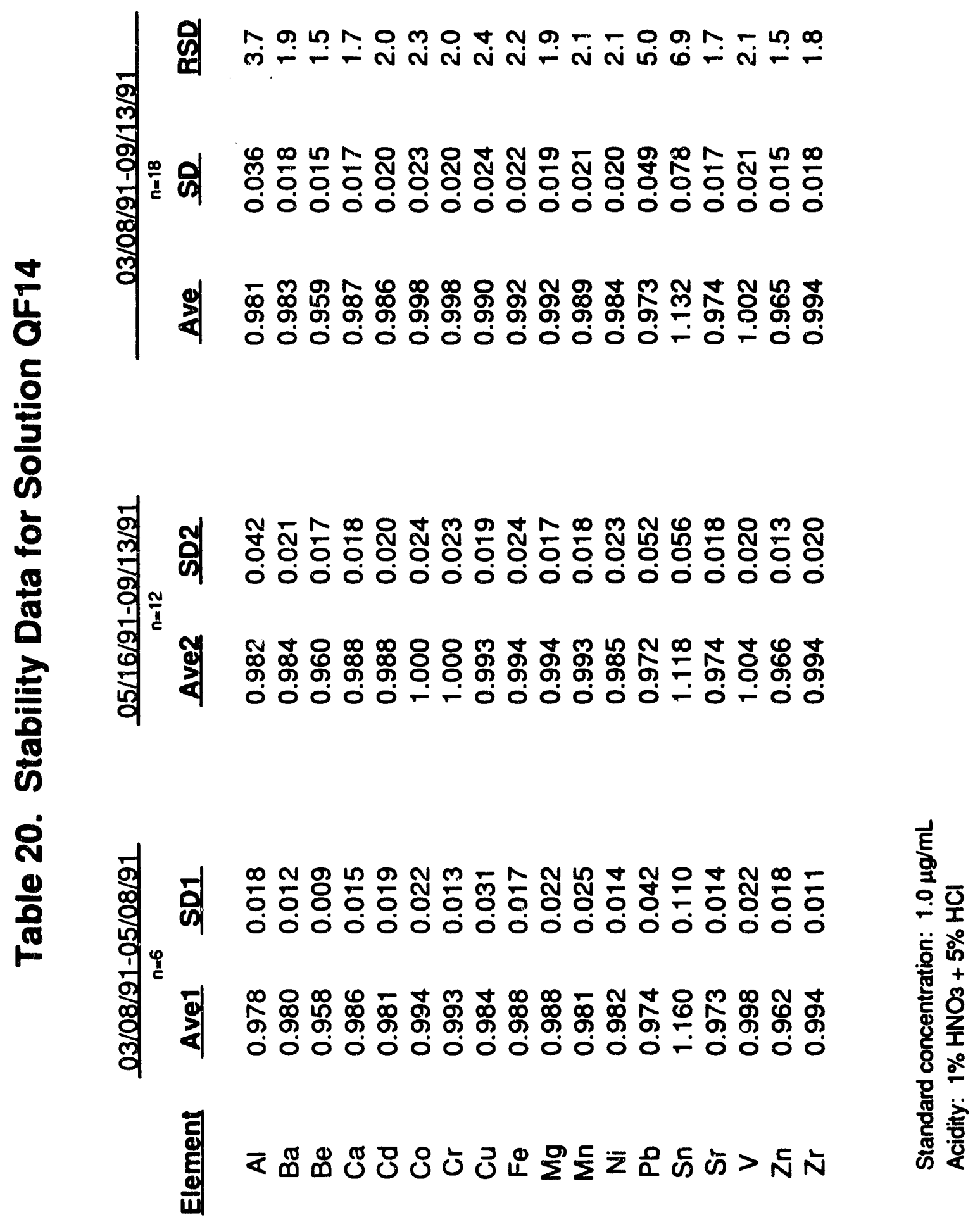




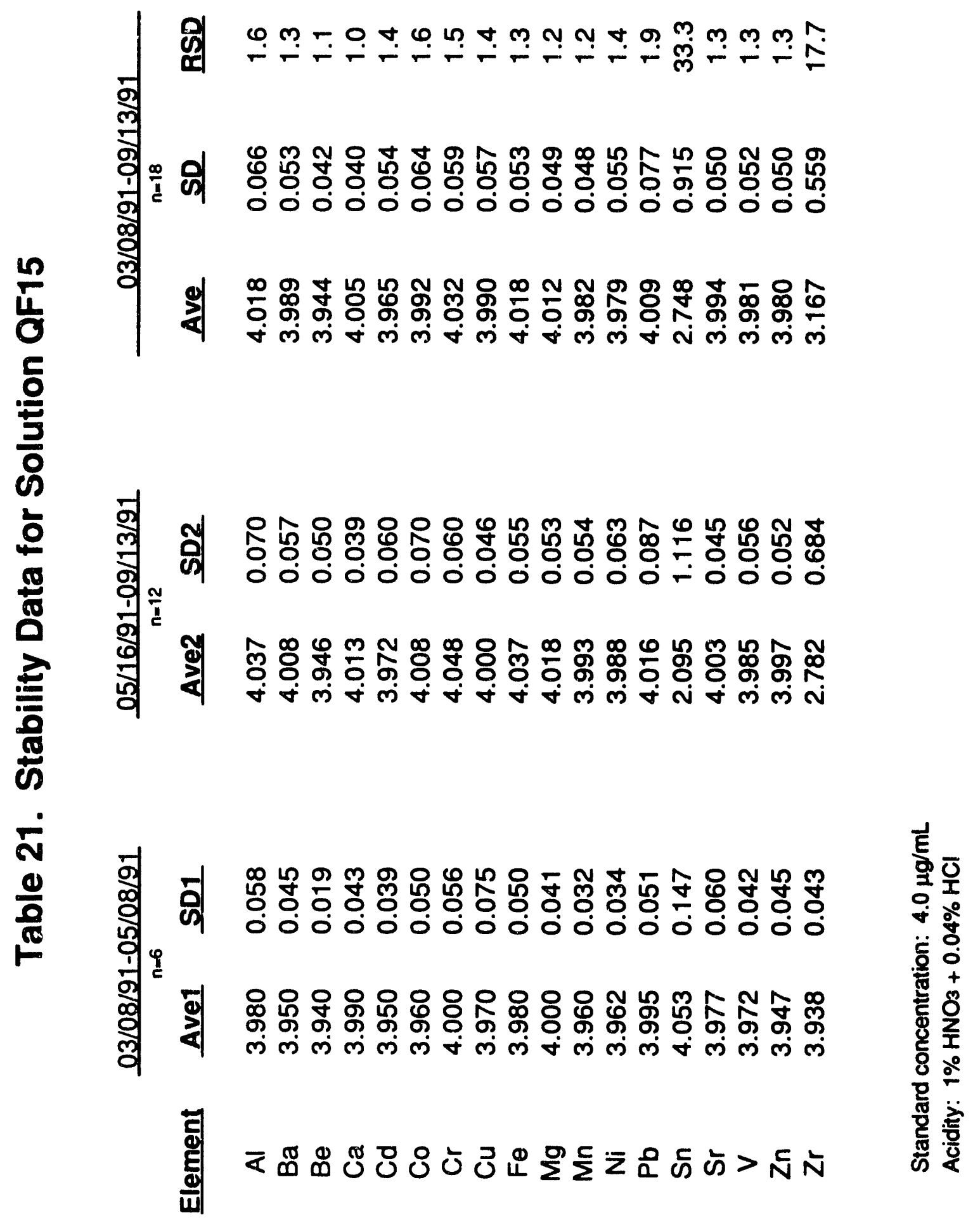




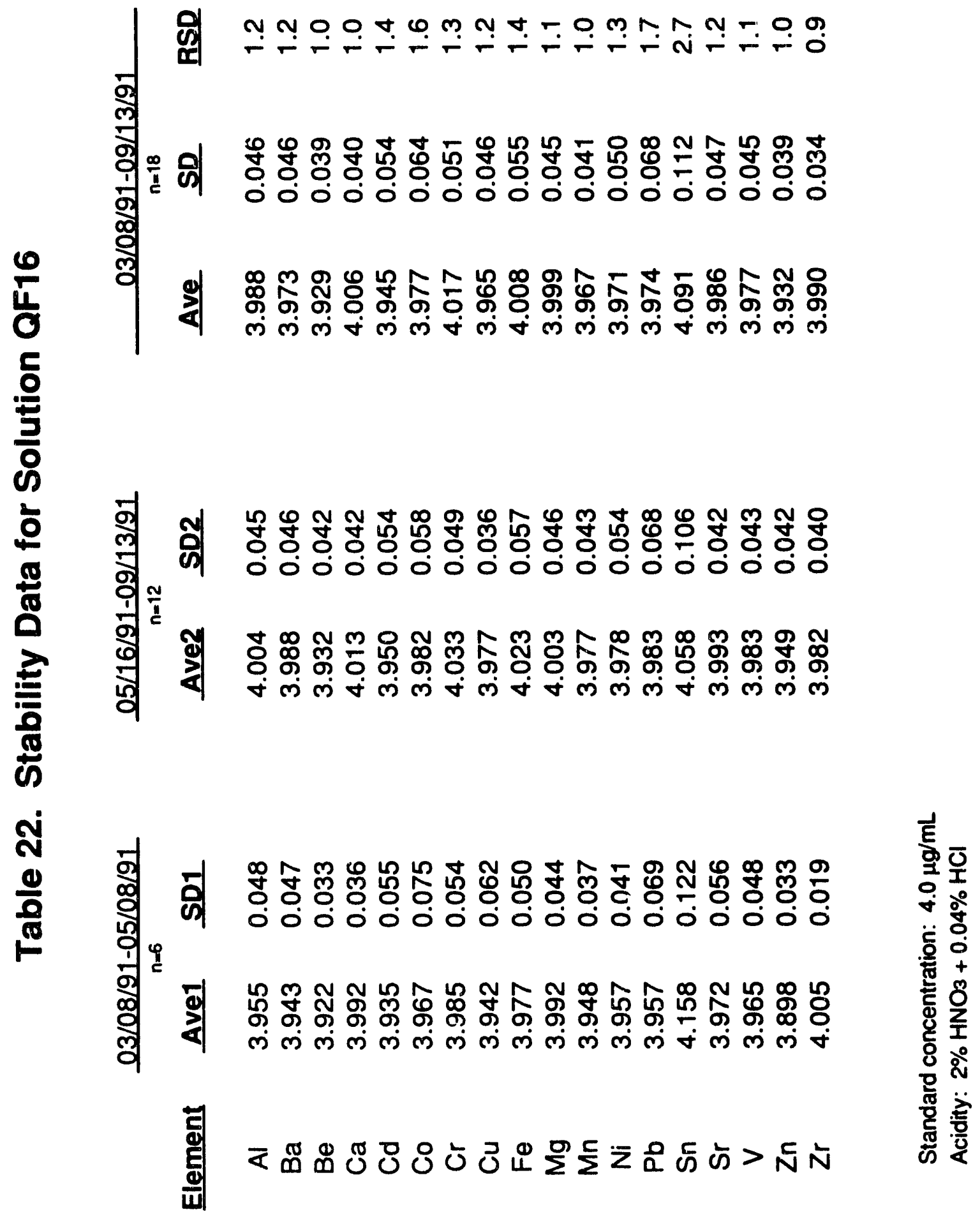




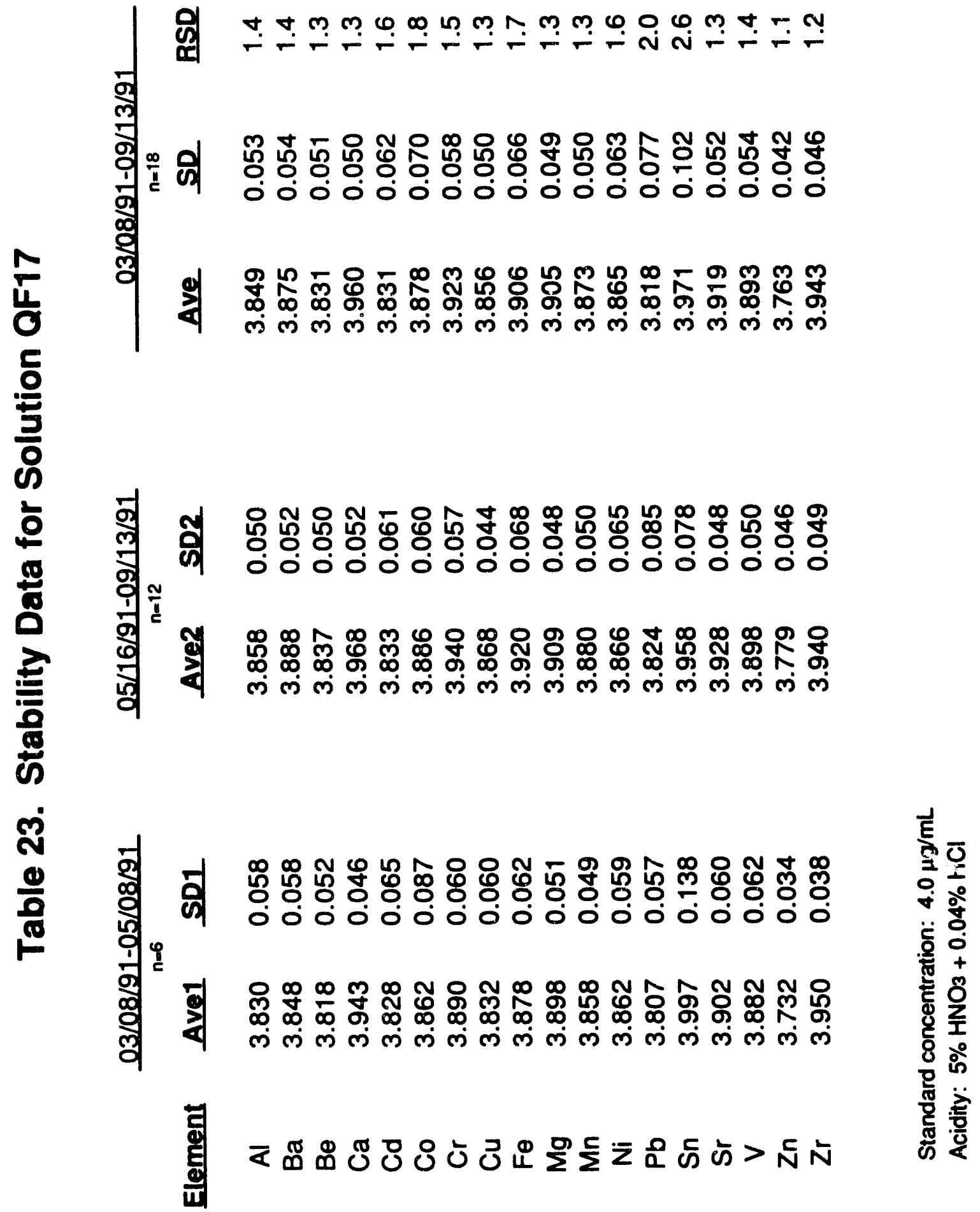




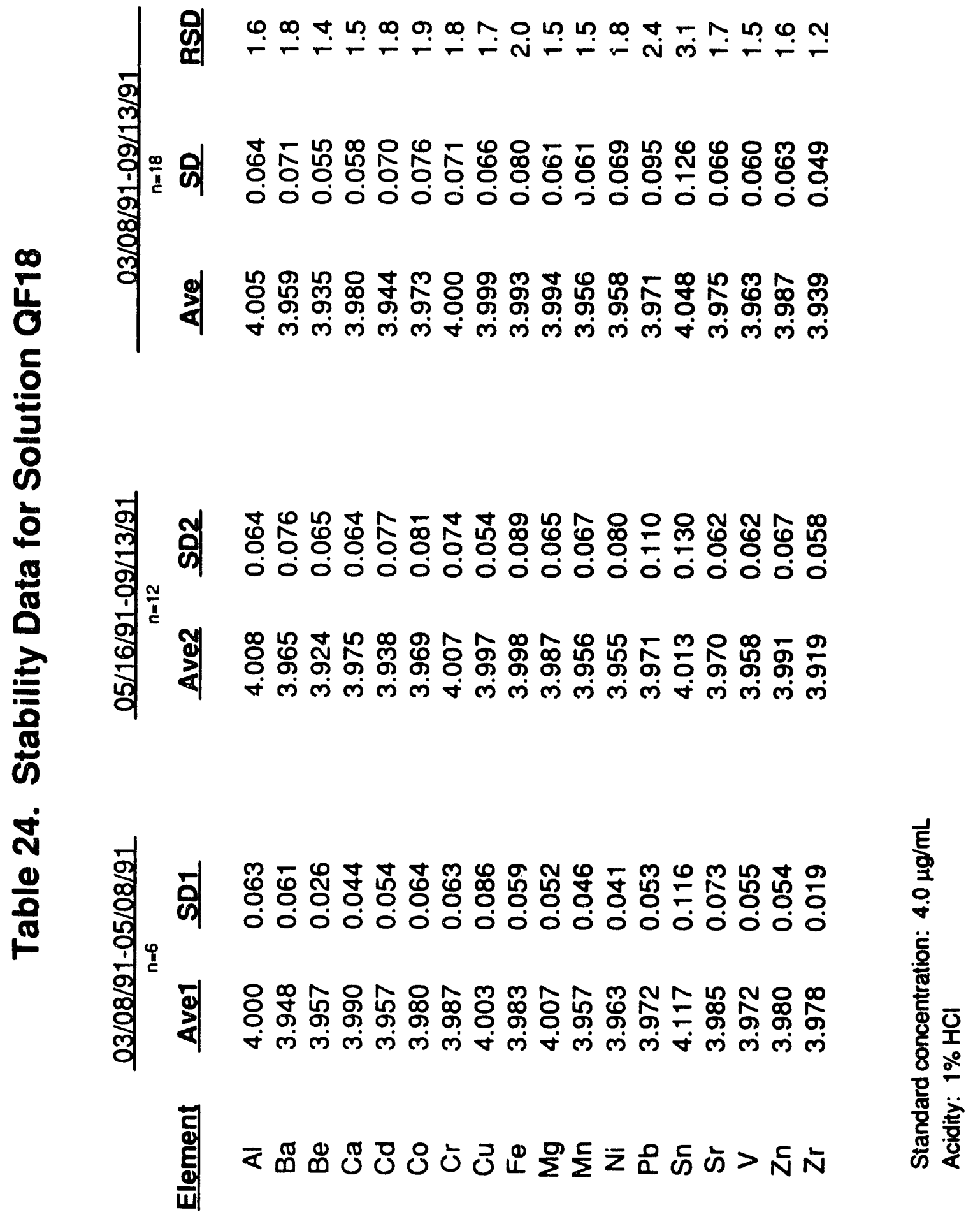




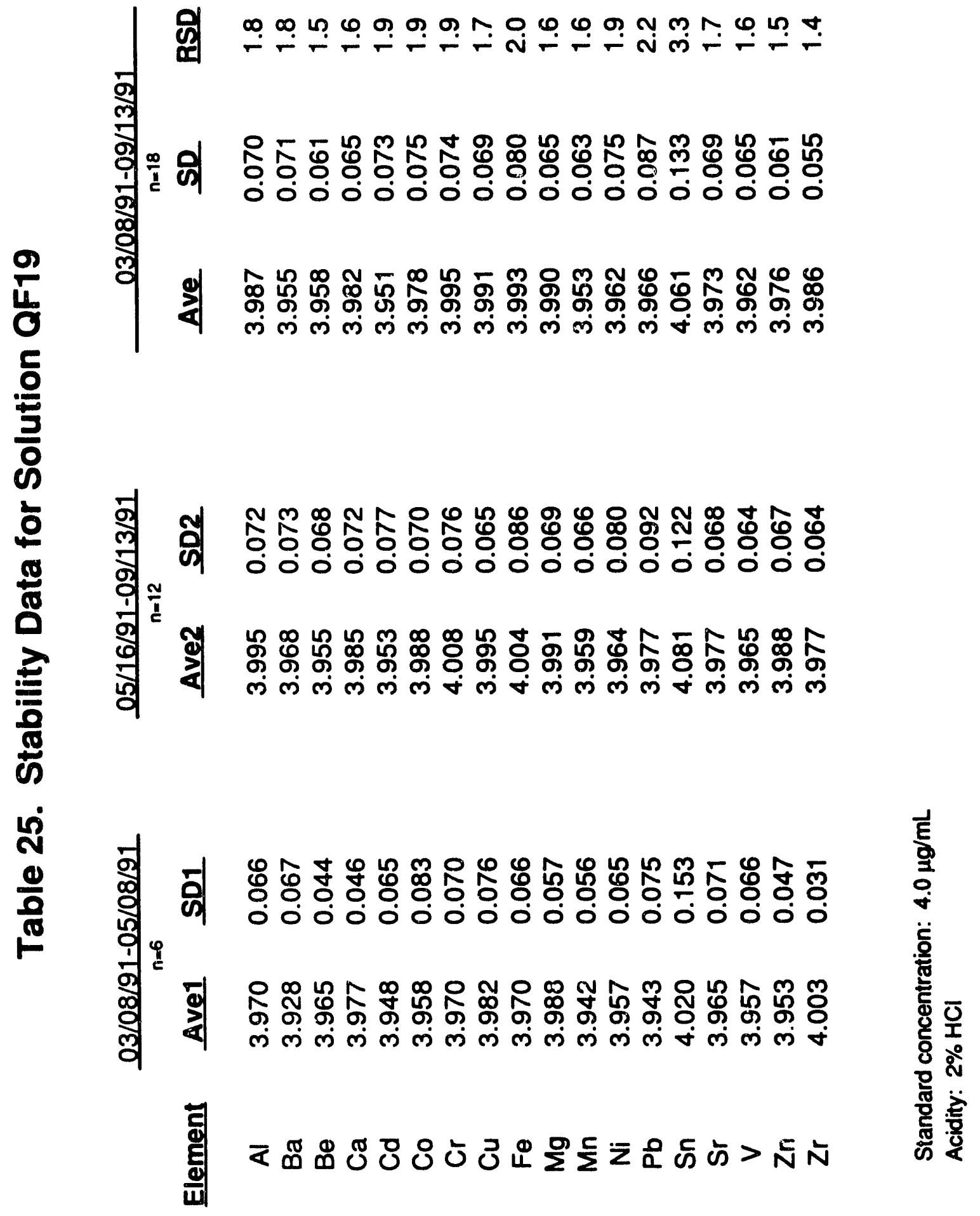


웜

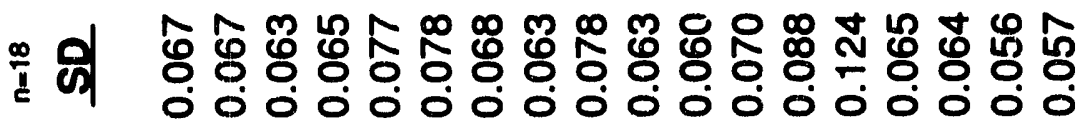

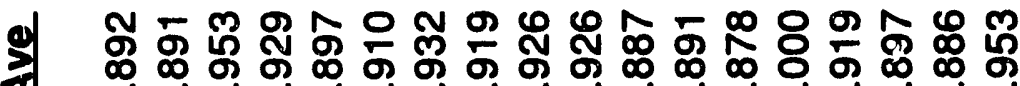

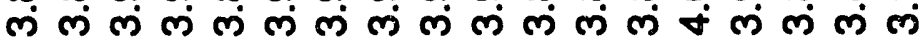

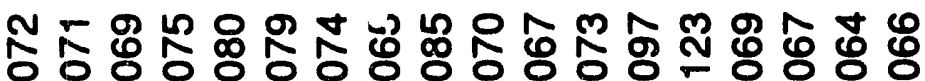

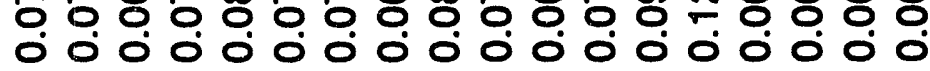

மூ9

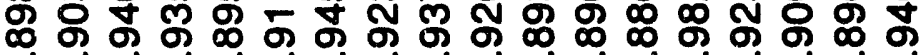

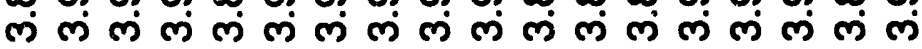

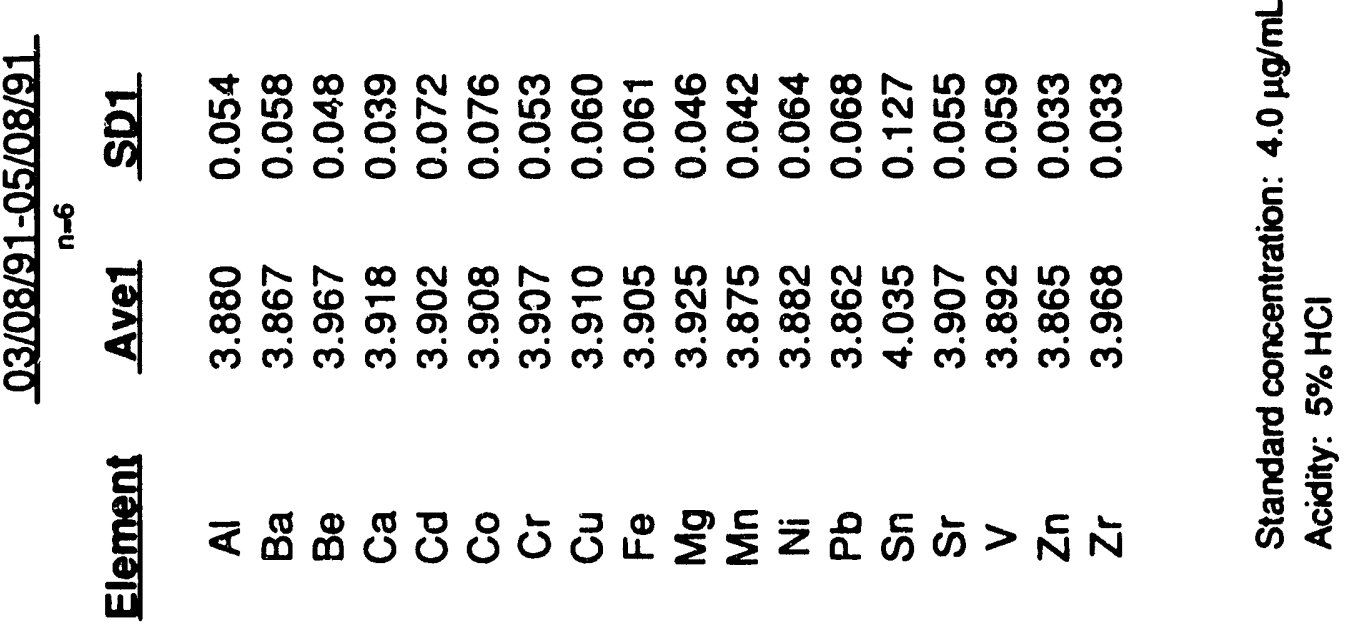




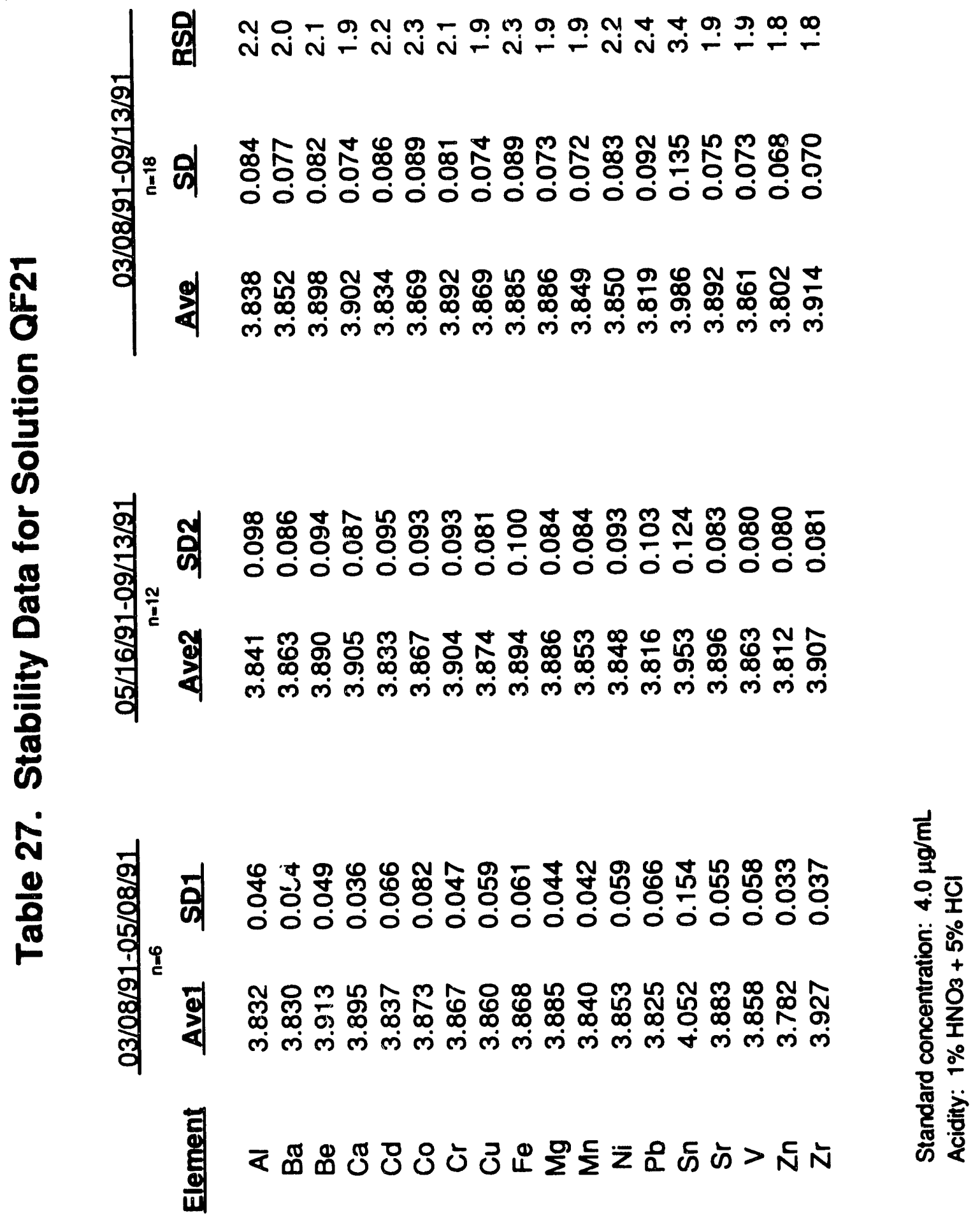




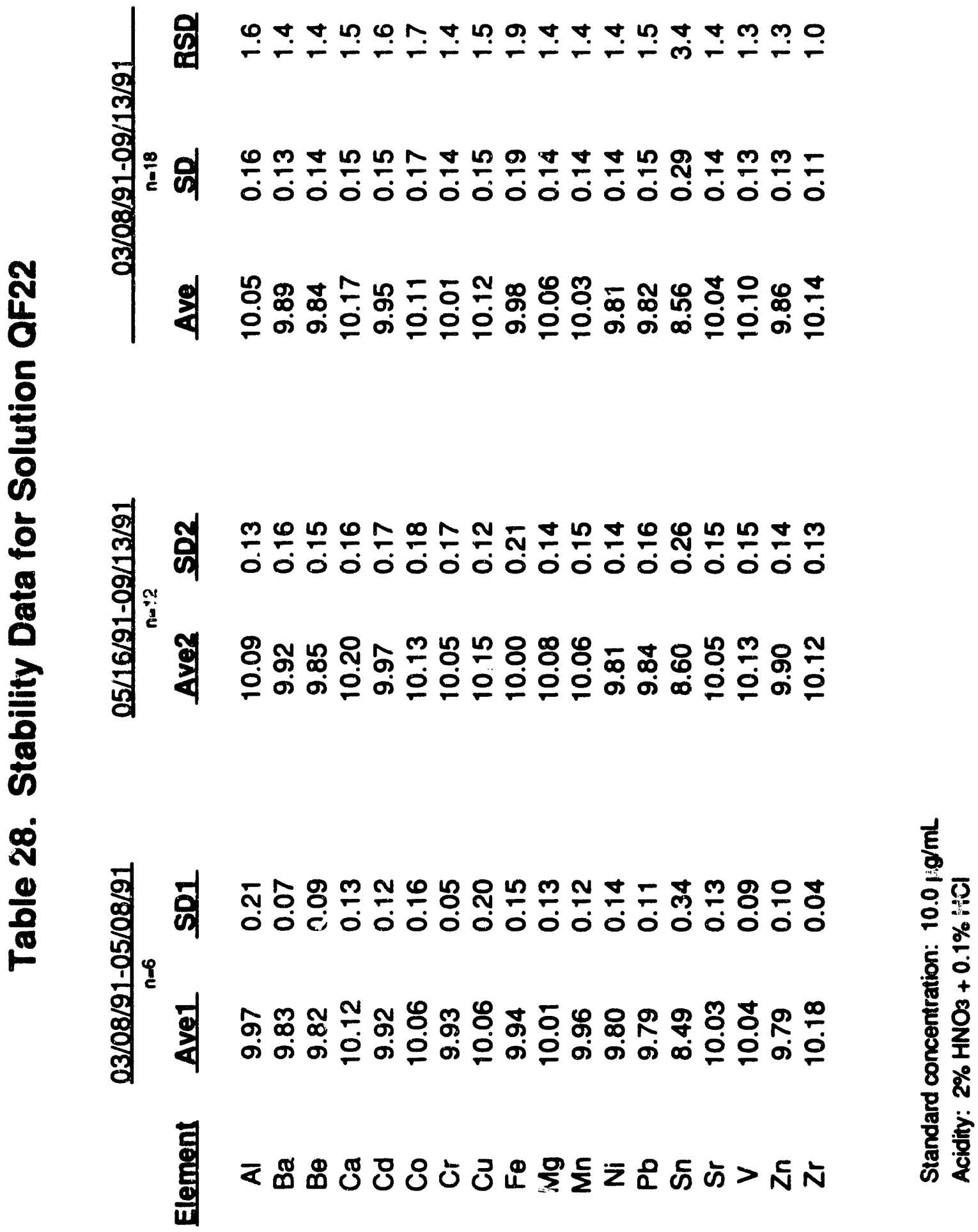




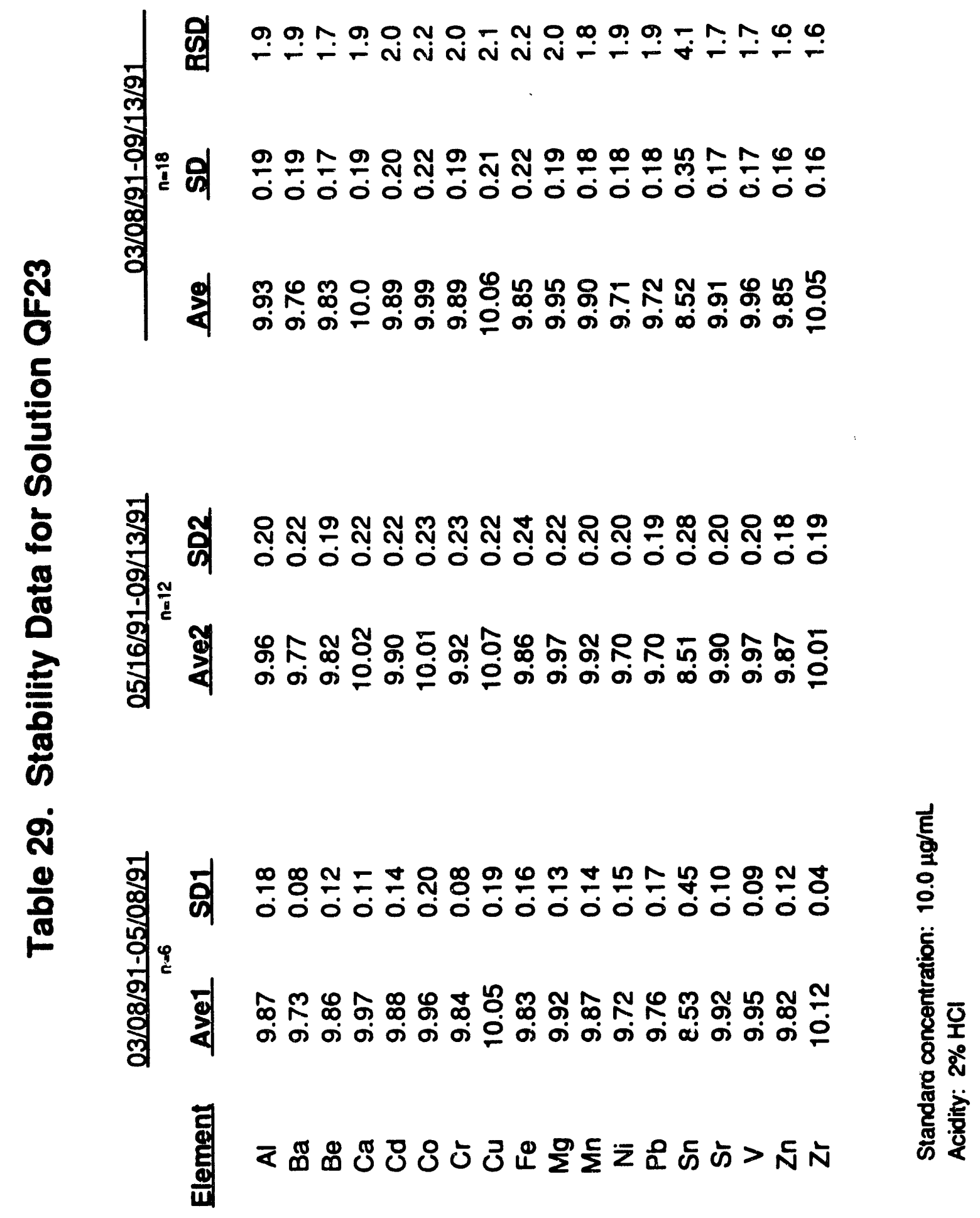


웜

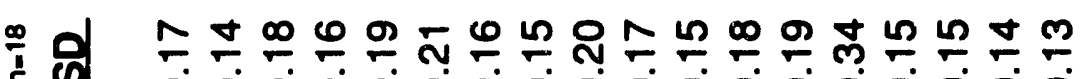

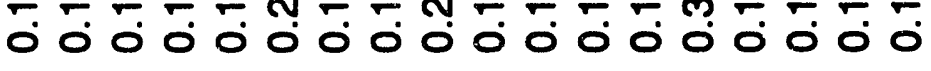

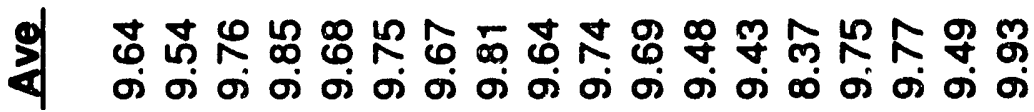

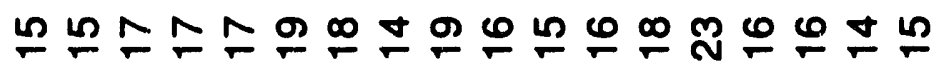

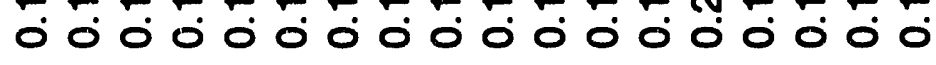

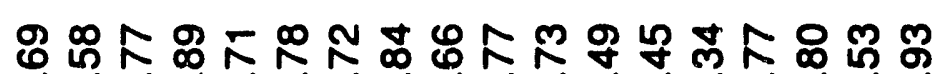

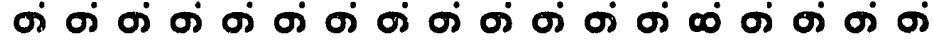

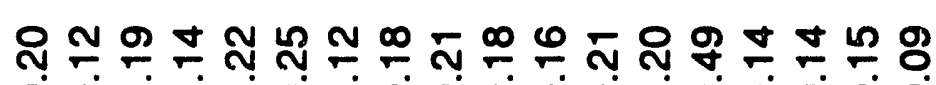

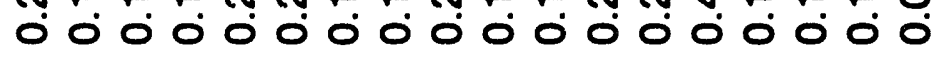

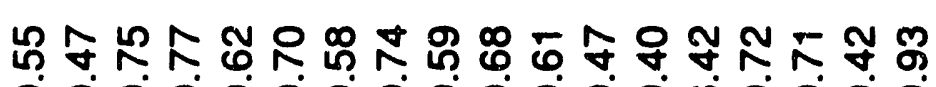

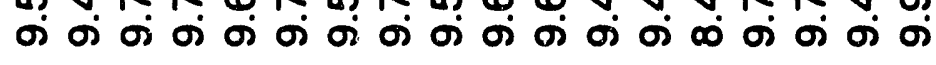

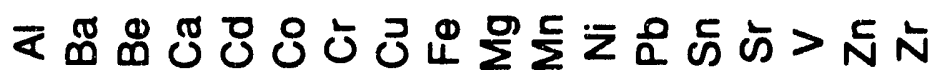

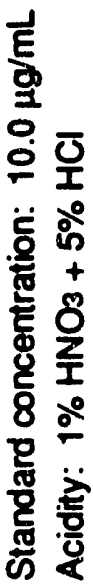




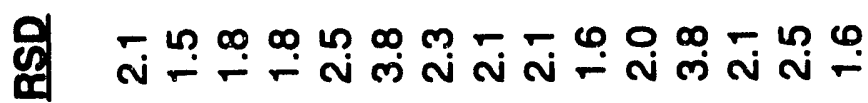

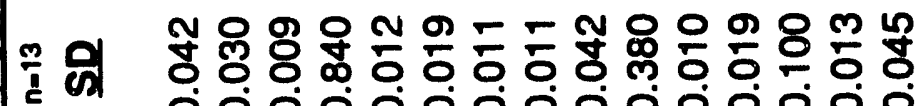

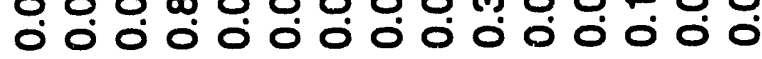

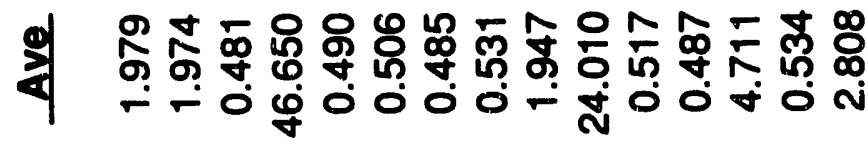

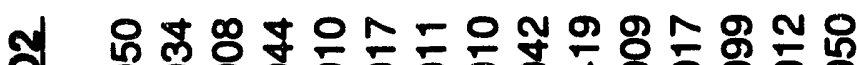

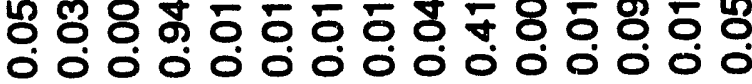

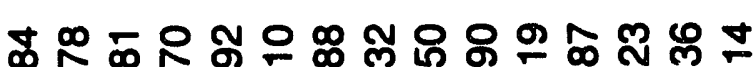

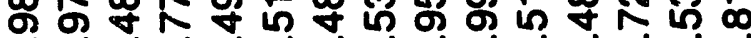

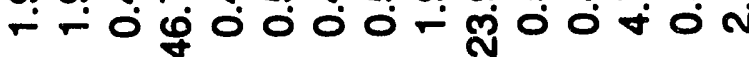

웡 영

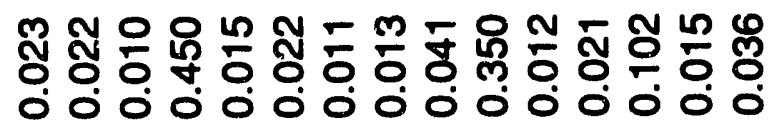

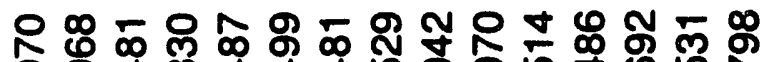
ล\% \%

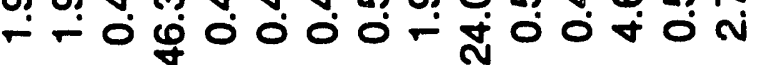

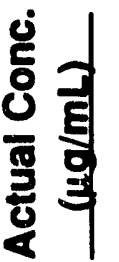

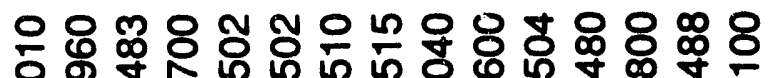

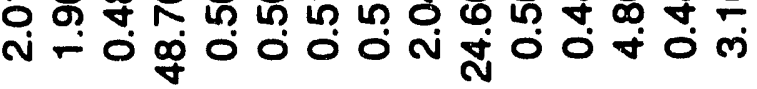

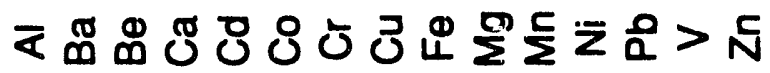


응

里

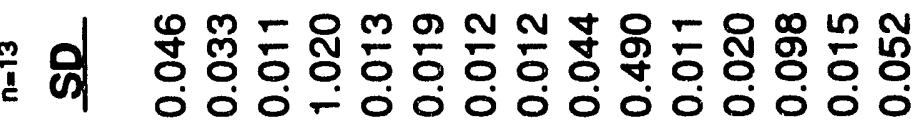

잉

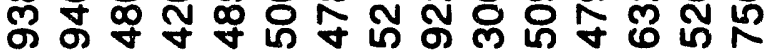

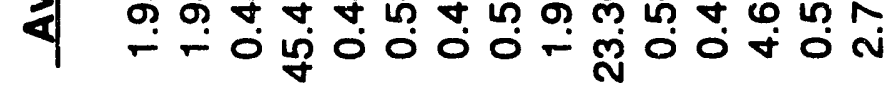

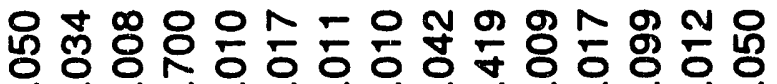

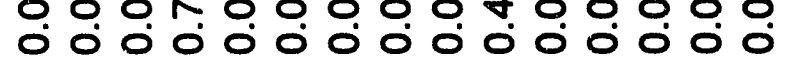

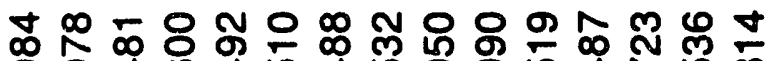

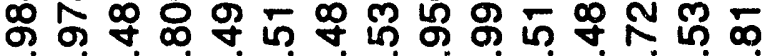

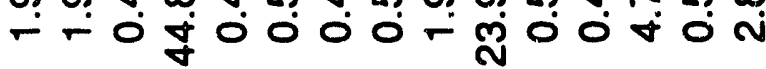

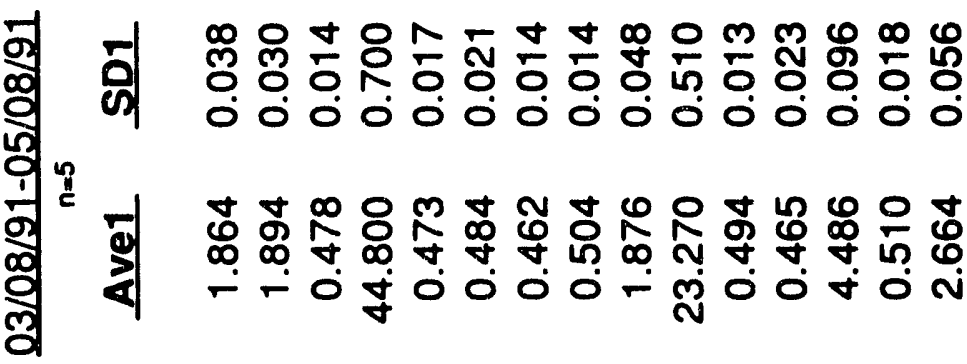

迄

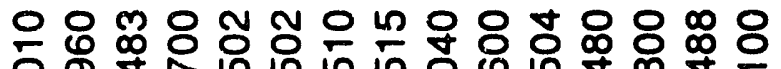
N -0 o 0000 i

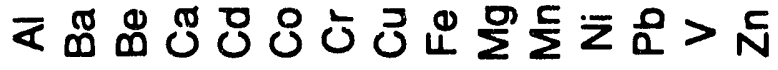




\section{Table 33. Stability Data for Silver Solutions}

\begin{tabular}{|c|c|c|c|c|c|c|}
\hline \multirow[b]{2}{*}{ File " } & \multicolumn{3}{|c|}{$03 / 08 / 91-05 / 08 / 91$} & \multicolumn{3}{|c|}{$03 / 08 / 91-09 / 13 / 91$} \\
\hline & Ave1 $^{b}$ & $\begin{array}{c}n=6 \\
\mathrm{SD1}\end{array}$ & RSD1 & Ave & $\begin{array}{l}n=17 \\
S D\end{array}$ & RSD \\
\hline QA01 & 0.205 & 0.006 & 2.9 & 0.204 & 0.008 & 3.9 \\
\hline QA02 & 0.199 & 0.006 & 3.0 & 1.200 & 0.007 & 3.5 \\
\hline QA03 & 0.190 & 0.005 & 2.6 & 0.189 & 0.007 & 3.7 \\
\hline QA04 & 1.042 & 0.017 & 1.6 & 1.039 & 0.018 & 1.7 \\
\hline QA05 & 1.022 & 0.016 & 1.6 & 1.023 & 0.017 & 1.7 \\
\hline QA06 & 0.990 & 0.012 & 1.2 & 0.990 & 0.015 & 1.5 \\
\hline QA07 & 4.057 & 0.057 & 1.4 & 4.036 & 0.056 & 1.4 \\
\hline QA08 & 4.002 & 0.072 & 1.8 & 3.998 & 0.060 & 1.5 \\
\hline QA09 & 3.882 & 0.065 & 1.7 & 3.886 & 0.052 & 1.3 \\
\hline QA10 & 10.18 & 0.16 & 1.6 & 10.06 & 0.19 & 1.9 \\
\hline QIC1 & 0.516 & 0.016 & 3.1 & 0.520 & 0.017 & 3.3 \\
\hline QIC2 & 0.489 & 0.015 & 3.1 & 0.492 & 0.018 & 3.6 \\
\hline
\end{tabular}

Table 34. Stability Data for Tin Solutions

\begin{tabular}{|c|c|c|c|c|c|c|}
\hline \multirow[b]{2}{*}{ Elle " } & \multicolumn{3}{|c|}{$03 / 08 / 91-05 / 08 / 91$} & \multicolumn{3}{|c|}{$03 / 08 / 91-0,9 / 13 / 91$} \\
\hline & Ave1 $^{b}$ & $\begin{array}{c}n=6 \\
\text { SD1 }\end{array}$ & RSD1 & Ave & $\begin{array}{l}n=17 \\
\mathbf{S D}\end{array}$ & RSD \\
\hline QSn2 & 4.278 & 0.099 & 2.3 & 4.282 & 0.082 & 1.9 \\
\hline QSn3 & 4.825 & 0.101 & 2.1 & 4.852 & 0.111 & 2.3 \\
\hline QSn5 & 19.85 & 0.58 & 2.9 & 18.16 & 2.18 & 12.0 \\
\hline QSn6 & 19.12 & 0.36 & 1.9 & 19.12 & 0.34 & 1.8 \\
\hline
\end{tabular}


Table 35. Stability Data for Solutions QSi

Element

$\frac{03 / 08 / 91-05 / 08 / 91}{\text { Ave1 }^{n} \quad \text { SD1 }^{n-6} \text { RSD1 }}$

03/08/91-09/13/91

$\begin{array}{ll}\text { Ave } & \text { SD } \\ & \text { BSD }\end{array}$

QSi1: $2 \%$ HNO3

$\begin{array}{ccccccc}\text { B } & 0.493 & 0.009 & 1.8 & 0.492 & 0.016 & 3.2 \\ \mathrm{Mo} & 0.497 & 0.019 & 3.8 & 0.494 & 0.021 & 4.2 \\ \mathrm{Si} & 1.048 & 0.027 & 2.6 & 1.045 & 0.055 & 5.3 \\ \mathrm{Ti} & 0.503 & 0.015 & 1.0 & 0.507 & 0.005 & 1.0\end{array}$

QSi2: $2 \% \mathrm{HCl}$

$\begin{array}{ccccccc}\text { B } & 0.508 & 0.011 & 2.2 & 0.516 & 0.017 & 3.3 \\ \text { Mo } & 0.511 & 0.017 & 3.3 & 0.517 & 0.019 & 3.7 \\ \mathrm{Si} & 1.030 & 0.014 & 1.3 & 1.035 & 0.053 & 5.1 \\ \mathrm{Ti} & 0.498 & 0.004 & 0.8 & 0.504 & 0.007 & 1.4\end{array}$

QSi3: $5 \% \mathrm{HCl}+1 \% \mathrm{HNO}$

$\begin{array}{ccccccc}\text { B } & 0.518 & 0.019 & 3.7 & 0.522 & 0.021 & 4.0 \\ \text { Mo } & 0.505 & 0.015 & 3.0 & 0.509 & 0.017 & 3.3 \\ \mathrm{Si} & 1.006 & 0.042 & 4.2 & 1.029 & 0.059 & 5.7 \\ \mathrm{Ti} & 0.487 & 0.007 & 1.4 & 0.494 & 0.012 & 2.4\end{array}$

QSI4: $2 \%$ HNO3

$\begin{array}{ccccccc}\text { B } & 2.437 & 0.016 & 0.7 & 2.405 & 0.072 & 3.0 \\ \text { Mo } & 2.452 & 0.018 & 0.7 & 2.446 & 0.040 & 1.6 \\ \mathrm{Si} & 5.205 & 0.107 & 2.0 & 5.137 & 0.241 & 4.7 \\ \mathrm{Ti} & 2.495 & 0.024 & 1.0 & 2.495 & 0.067 & 2.7\end{array}$

QSi5: $2 \% \mathrm{HCl}$

$\begin{array}{cllllll}\text { B } & 2.533 & 0.027 & 1.1 & 2.519 & 0.103 & 4.1 \\ \text { Mo } & 2.487 & 0.043 & 1.7 & 2.489 & 0.045 & 1.8 \\ \mathrm{Si} & 5.128 & 0.052 & 1.0 & 5.159 & 0.215 & 4.2 \\ \mathrm{Ti} & 2.480 & 0.019 & 0.8 & 2.505 & 0.048 & 1.9\end{array}$


Table 35. Stability Data for Solutions QSi (contd)

\begin{tabular}{|c|c|c|c|c|c|c|}
\hline \multirow[b]{2}{*}{ Element } & \multicolumn{3}{|c|}{$03 / 08 / 91-05 / 08 / 91$} & \multicolumn{3}{|c|}{$03 / 08 / 91-09 / 13 / 91$} \\
\hline & Ave1 & $\begin{array}{c}n-6 \\
\text { SD1 }\end{array}$ & RSD1 & Ave" & $\begin{array}{l}n=17 \\
\text { SD }\end{array}$ & RSD \\
\hline & \multicolumn{6}{|c|}{ QSi6: $5 \% \mathrm{HCl}+1 \% \mathrm{HNO}$} \\
\hline B & 2.543 & 0.037 & 1.4 & 2.536 & 0.103 & 4.1 \\
\hline Mo & 2.462 & 0.043 & 1.7 & 2.468 & 0.045 & 1.8 \\
\hline $\mathrm{Si}$ & 5.017 & 0.075 & 1.5 & 5.076 & 0.215 & 4.2 \\
\hline $\mathrm{Ti}$ & 2.422 & 0.028 & 1.1 & 2.461 & 0.048 & 1.9 \\
\hline
\end{tabular}

QS17: $2 \% \mathrm{HNO}_{3}$

$\begin{array}{ccccccc}\mathrm{B} & 9.83 & 0.09 & 0.9 & 9.78 & 0.12 & 1.2 \\ \mathrm{Mo} & 9.89 & 1.60 & 1.6 & 9.95 & 0.15 & 1.5 \\ \mathrm{Si} & 20.77 & 0.51 & 2.4 & 21.06 & 0.76 & 3.6 \\ \mathrm{Ti} & 10.06 & 0.08 & 0.8 & 10.13 & 0.17 & 1.7\end{array}$

QSI8: $2 \% \mathrm{HCl}$

$\begin{array}{ccccccc}\text { B } & 10.03 & 0.12 & 1.2 & 10.01 & 0.11 & 1.1 \\ \mathrm{Mo} & 9.89 & 0.11 & 1.1 & 9.87 & 0.15 & 1.5 \\ \mathrm{Si} & 20.32 & 0.34 & 1.7 & 20.68 & 0.81 & 3.9 \\ \mathrm{Ti} & 9.81 & 0.10 & 1.0 & 9.92 & 0.16 & 1.6\end{array}$

QSi9: $5 \% \mathrm{HCl}+1 \% \mathrm{HNO}$

$\begin{array}{ccccccc}\text { B } & 10.01 & 0.11 & 1.1 & 10.03 & 0.12 & 1.2 \\ \mathrm{Mo} & 9.69 & 0.08 & 0.8 & 9.73 & 0.14 & 1.4 \\ \mathrm{Si} & 19.82 & 0.26 & 1.3 & 20.25 & 0.75 & 3.7 \\ \mathrm{Ti} & 9.67 & 0.10 & 1.0 & 9.78 & 0.19 & 1.9\end{array}$




\section{Table 36. Stability Data for Solutions QAs}

\begin{tabular}{|c|c|c|c|c|c|c|}
\hline \multirow[b]{2}{*}{ Element } & \multicolumn{3}{|c|}{$03 / 08 / 91-05 / 08 / 91$} & \multicolumn{3}{|c|}{$03 / 08 / 91-09 / 13 / 91$} \\
\hline & Ave1 " & $\begin{array}{l}n-6 \\
\text { SD1 }\end{array}$ & RSD1 & Ave" & $\begin{array}{l}n=18 \\
\text { SD }\end{array}$ & RSD \\
\hline & & & 2As1: & & & \\
\hline As & 5.058 & 0.054 & 1.1 & 5.087 & 0.083 & 1.6 \\
\hline $\mathrm{Sb}$ & 5.183 & 0.080 & 1.5 & 5.418 & 0.373 & 6.9 \\
\hline $\mathrm{Se}$ & 4.893 & 0.047 & 1.0 & 4.862 & 0.101 & 2.1 \\
\hline
\end{tabular}

QAs2: $2 \% \mathrm{HCl}$

As

$\mathrm{Sb}$

Se

As

$\mathrm{Sb}$

$\mathrm{Se}$

As

$\mathrm{Sb}$

Se

As

$\mathrm{Sb}$

$\mathrm{Se}$

As

$\mathrm{Sb}$

$\mathrm{Se}$ $\begin{array}{lll}4.973 & 0.082 & 1.6\end{array}$

$\begin{array}{lll}5.083 & 0.093 & 1.8\end{array}$

$\begin{array}{lll}4.855 & 0.107 & 2.2\end{array}$
5.008

$0.101 \quad 2.0$

5.313

$0.384 \quad 7.2$

4.803

0.124

2.6

QAs3: $5 \% \mathrm{HCl}+1 \%$ HNO3

$\begin{array}{lllllll}\text { As } & 4.917 & 0.067 & 1.4 & 4.961 & 0.115 & 2.3 \\ \text { Sb } & 5.020 & 0.126 & 2.5 & 5.249 & 0.368 & 7.0 \\ \text { Se } & 4.790 & 0.080 & 1.7 & 4.774 & 0.097 & 2.0\end{array}$

QAs4: 2\% HNO3

$\begin{array}{llllll}20.22 & 0.25 & 1.2 & 20.37 & 0.40 & 2.0 \\ 20.72 & 0.45 & 2.2 & 21.65 & 1.51 & 7.0 \\ 20.17 & 0.26 & 1.3 & 20.16 & 0.39 & 1.9\end{array}$

QAs5: $2 \% \mathrm{HCl}$

$\begin{array}{llllll}19.77 & 0.25 & 1.3 & 19.95 & 0.41 & 2.0 \\ 20.22 & 0.39 & 1.9 & 21.14 & 1.47 & 7.0 \\ 19.83 & 0.19 & 1.0 & 19.82 & 0.38 & 1.9\end{array}$

QAs6: $5 \% \mathrm{HCl}+1 \% \mathrm{HNO}$

$\begin{array}{lllllll}\text { As } & 19.33 & 0.31 & 1.6 & 19.61 & 0.38 & 1.9 \\ \text { Sb } & 19.72 & 0.42 & 2.1 & 20.72 & 1.45 & 7.0 \\ \text { Se } & 19.45 & 0.28 & 1.4 & 19.49 & 0.32 & 1.6\end{array}$


Table 37. Stability Data for Niobium Solutions

\begin{tabular}{|c|c|c|c|c|c|c|}
\hline \multirow[b]{2}{*}{ File " } & \multicolumn{3}{|c|}{$04 / 29 / 91-06 / 24 / 91$} & \multicolumn{3}{|c|}{$04 / 29 / 91-10 / 21 / 91$} \\
\hline & Ave1 $^{\circ}$ & $\begin{array}{c}n=6 \\
\text { SD1 }\end{array}$ & RSD1 & Ave & $\begin{array}{l}n=14 \\
\text { SD }\end{array}$ & RSD \\
\hline QNb1 & 0.918 & 0.020 & 2.2 & 0.895 & 0.027 & 3.0 \\
\hline QNb2 & 0.970 & 0.024 & 2.5 & 0.971 & 0.023 & 2.4 \\
\hline QNb3 & 4.820 & 0.187 & 3.9 & 4.440 & 0.419 & 9.4 \\
\hline QNb4 & 5.037 & 0.089 & 1.8 & 4.981 & 0.093 & 1.9 \\
\hline QNb5 & 20.00 & 0.26 & 1.3 & 20.00 & 0.32 & 1.6 \\
\hline QNb6 & 20.13 & 0.33 & 1.6 & 20.11 & 0.33 & 1.6 \\
\hline
\end{tabular}

Table 38. Stability Data for Tungsten Solutions

\begin{tabular}{|c|c|c|c|c|c|c|}
\hline \multirow[b]{2}{*}{ File } & \multicolumn{3}{|c|}{$04 / 29 / 91-06 / 24 / 91$} & \multicolumn{3}{|c|}{$04 / 29 / 91-10 / 21 / 91$} \\
\hline & Ave1 $^{\circ}$ & $\begin{array}{c}n=6 \\
\text { SD1 }\end{array}$ & RSD1 & Ave $^{b}$ & $\begin{array}{l}n=13 \\
\text { SD } \\
\end{array}$ & RSD \\
\hline QW01 & 0.961 & 0.013 & 1.4 & 0.960 & 0.023 & 2.4 \\
\hline QW02 & 0.987 & 0.027 & 2.7 & 0.987 & 0.037 & 3.7 \\
\hline QW03 & 4.842 & 0.041 & 0.8 & 4.320 & 0.739 & 17.1 \\
\hline QW04 & 4.953 & 0.052 & 1.0 & 4.950 & 0.056 & 1.1 \\
\hline QW05 & 19.93 & 0.07 & 0.4 & 17.20 & 3.49 & 20.3 \\
\hline QW06 & 20.17 & 0.15 & 0.7 & 20.09 & 0.21 & 1.0 \\
\hline
\end{tabular}


Figure 1. Signal-to-Background Ratio vs. Acidity

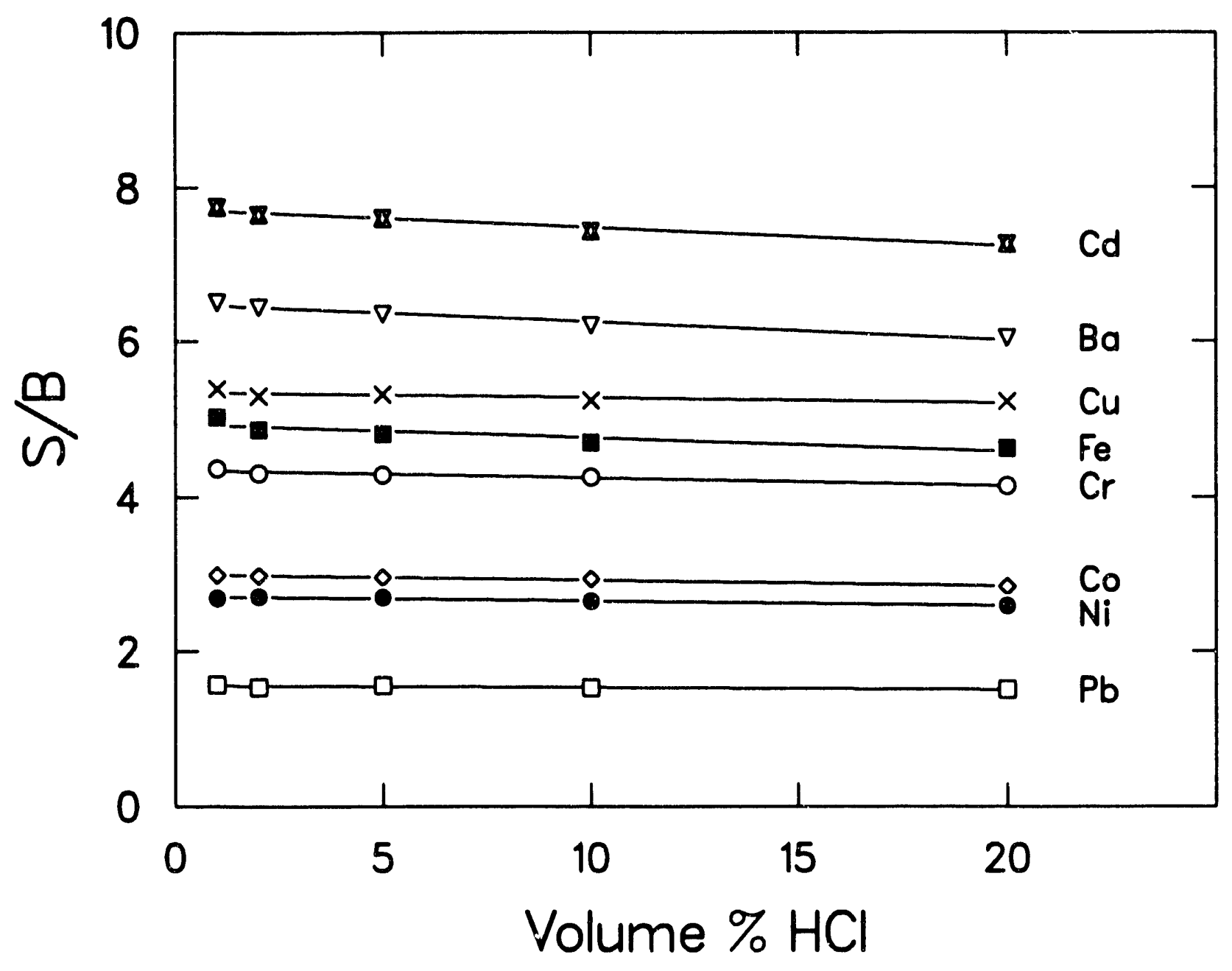


Figure 2. Relative Standard Deviation for Aluminum
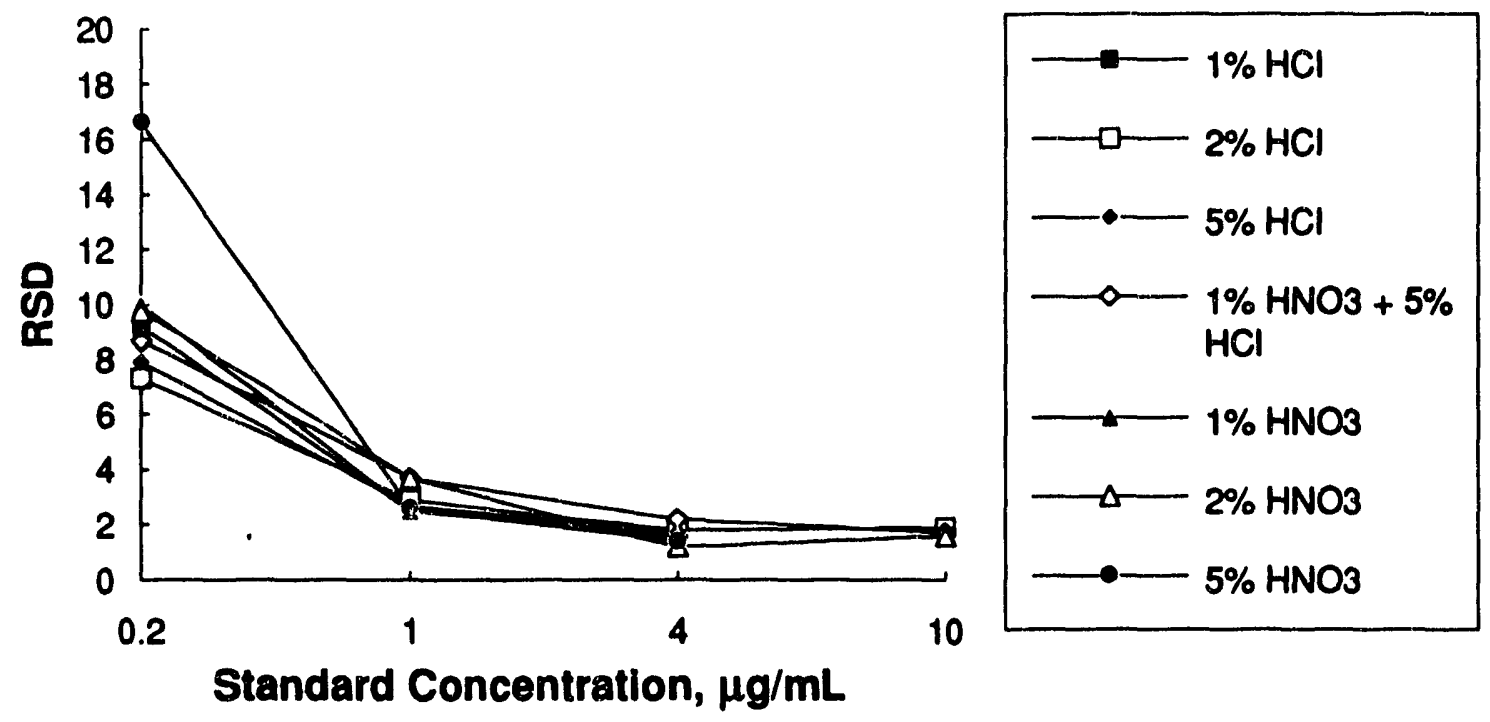

Standard Concentration, $\mu \mathrm{g} / \mathrm{mL}$

Figure 3. Relative Standard Deviation for Beryllium
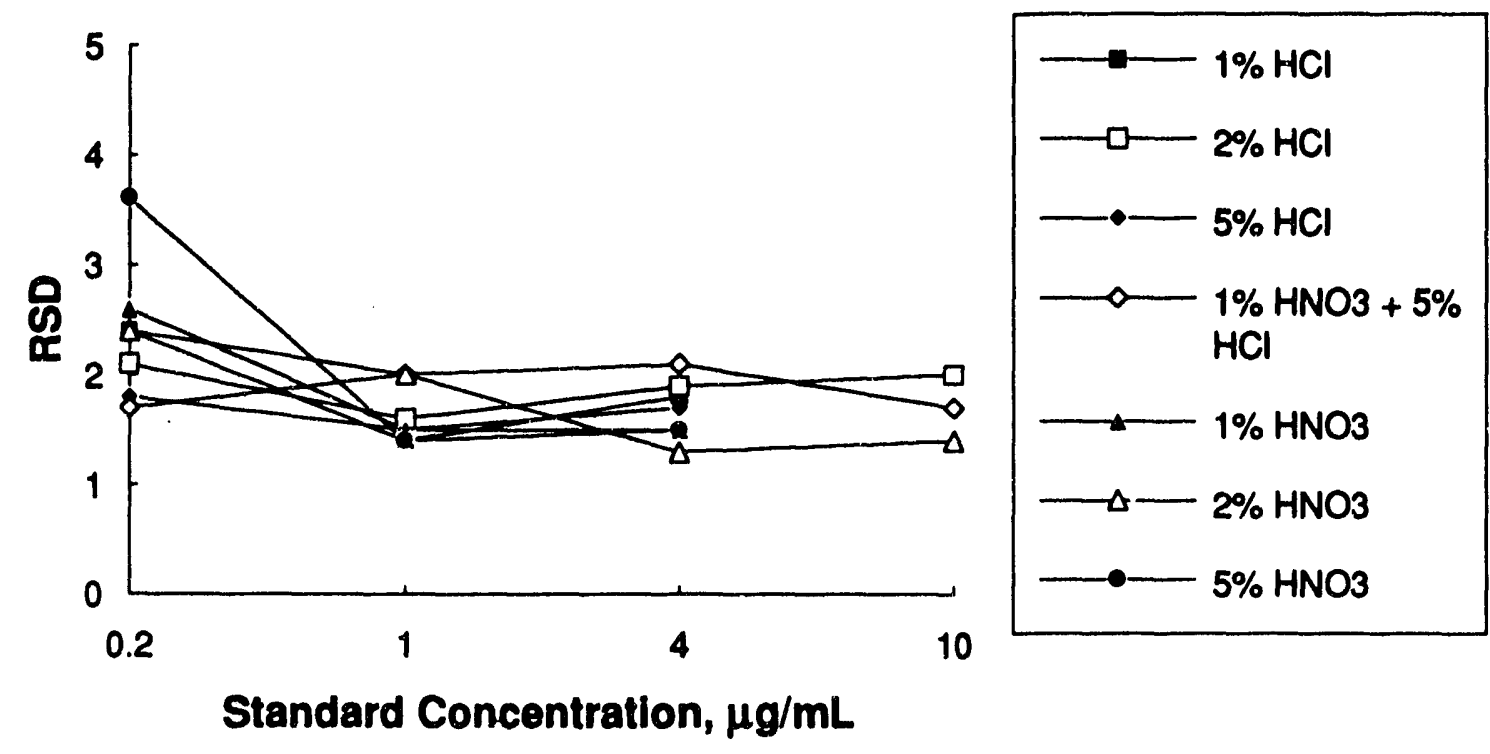

10 


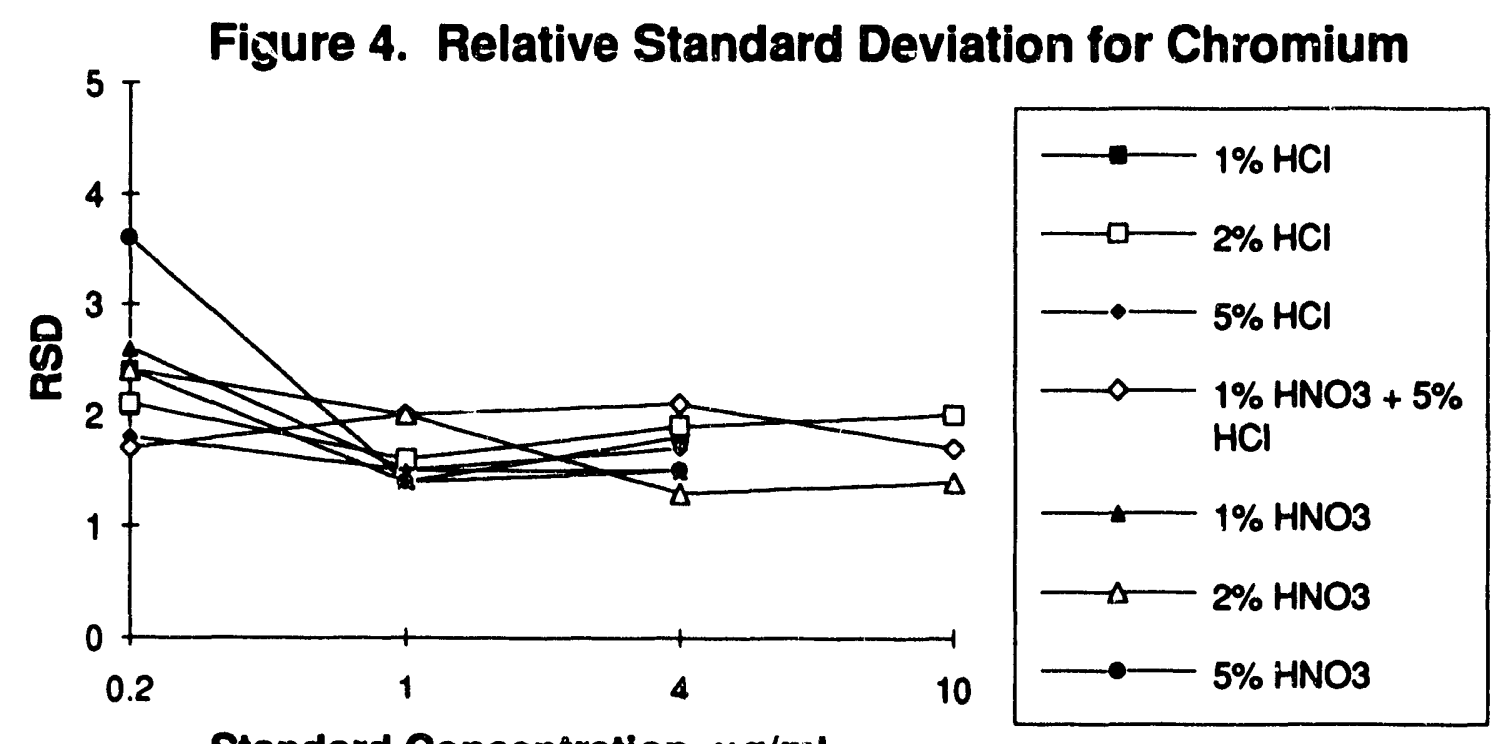

Standard Concentration, $\mu \mathrm{g} / \mathrm{mL}$

Figure 5. Relative Standard Deviation for Nickel
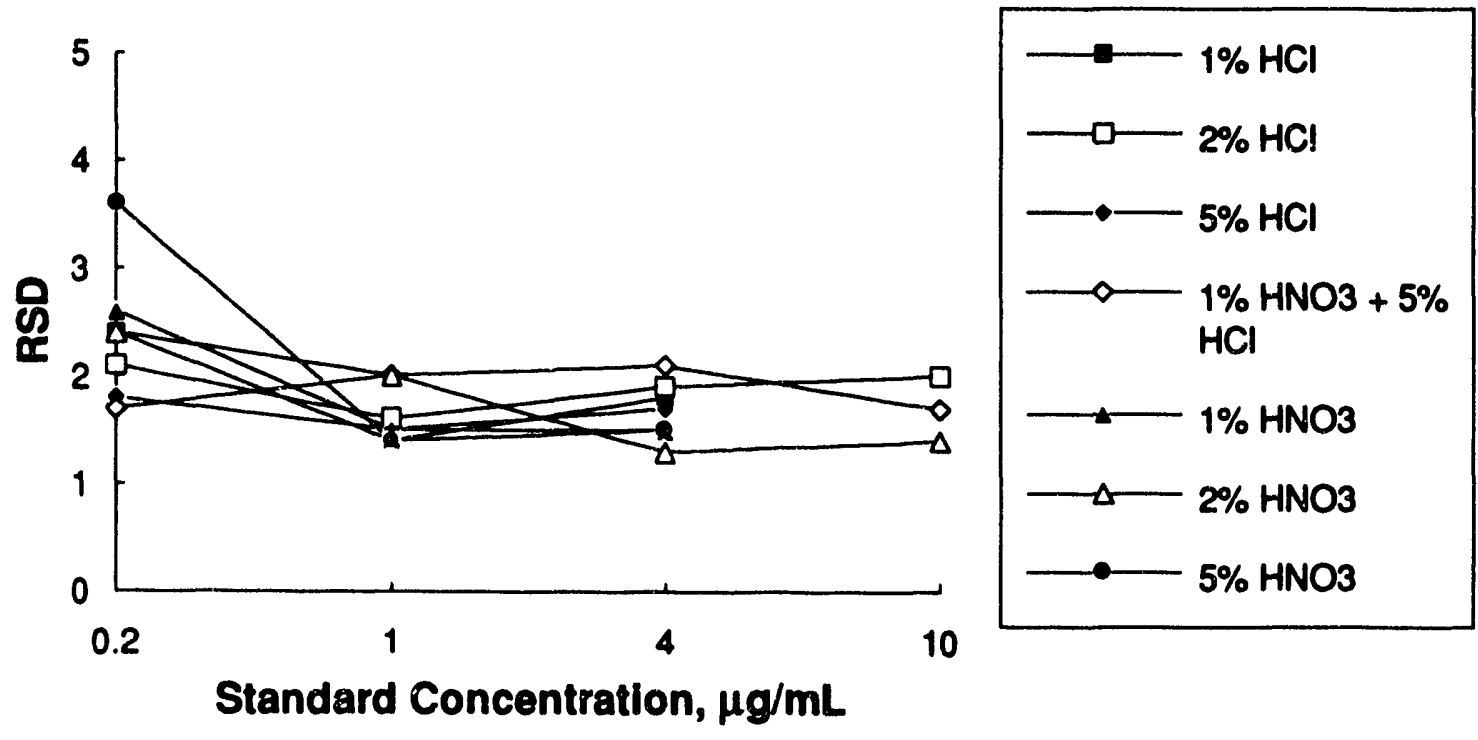
10 
Figure 6. Relative Standard Deviation for Lead
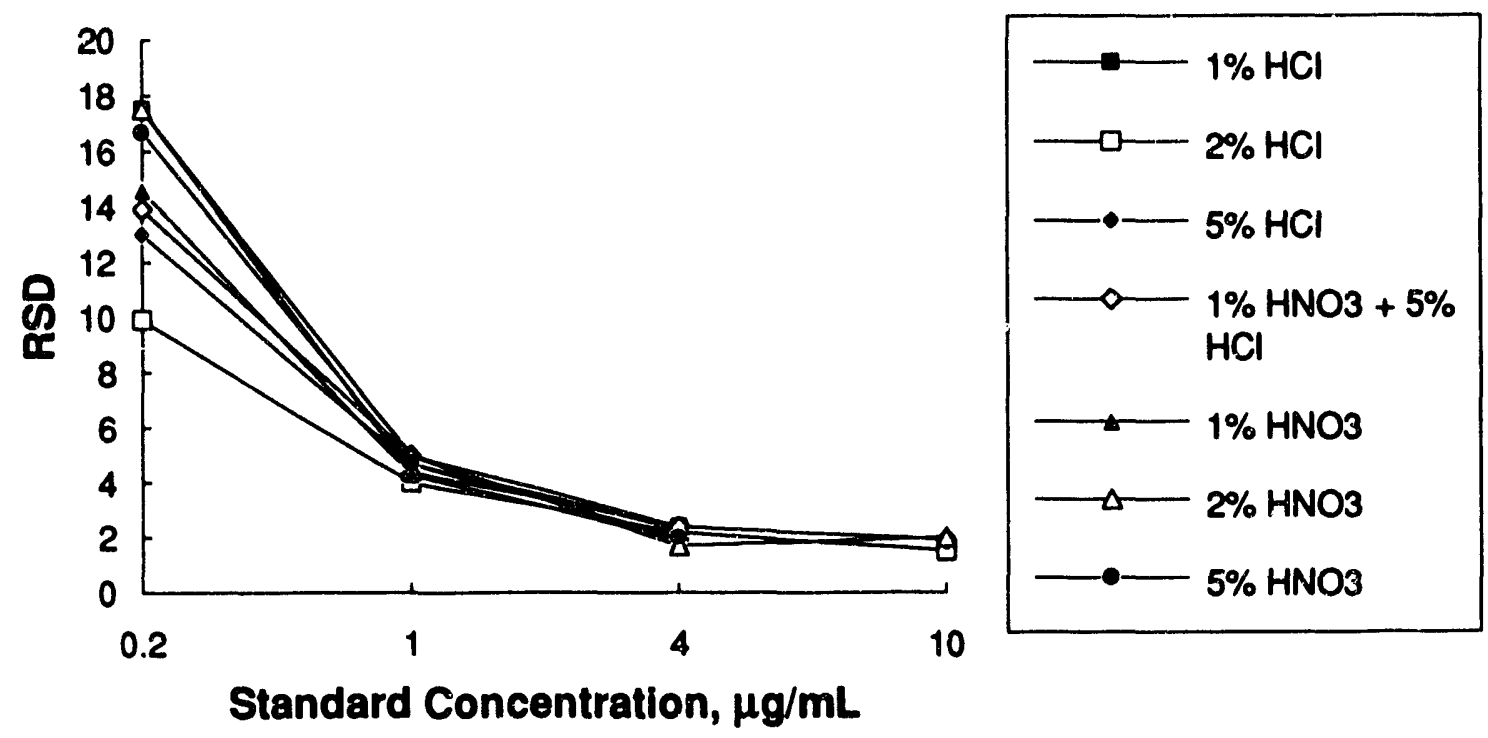

Figure 7. Relative Standard Deviation for Tin
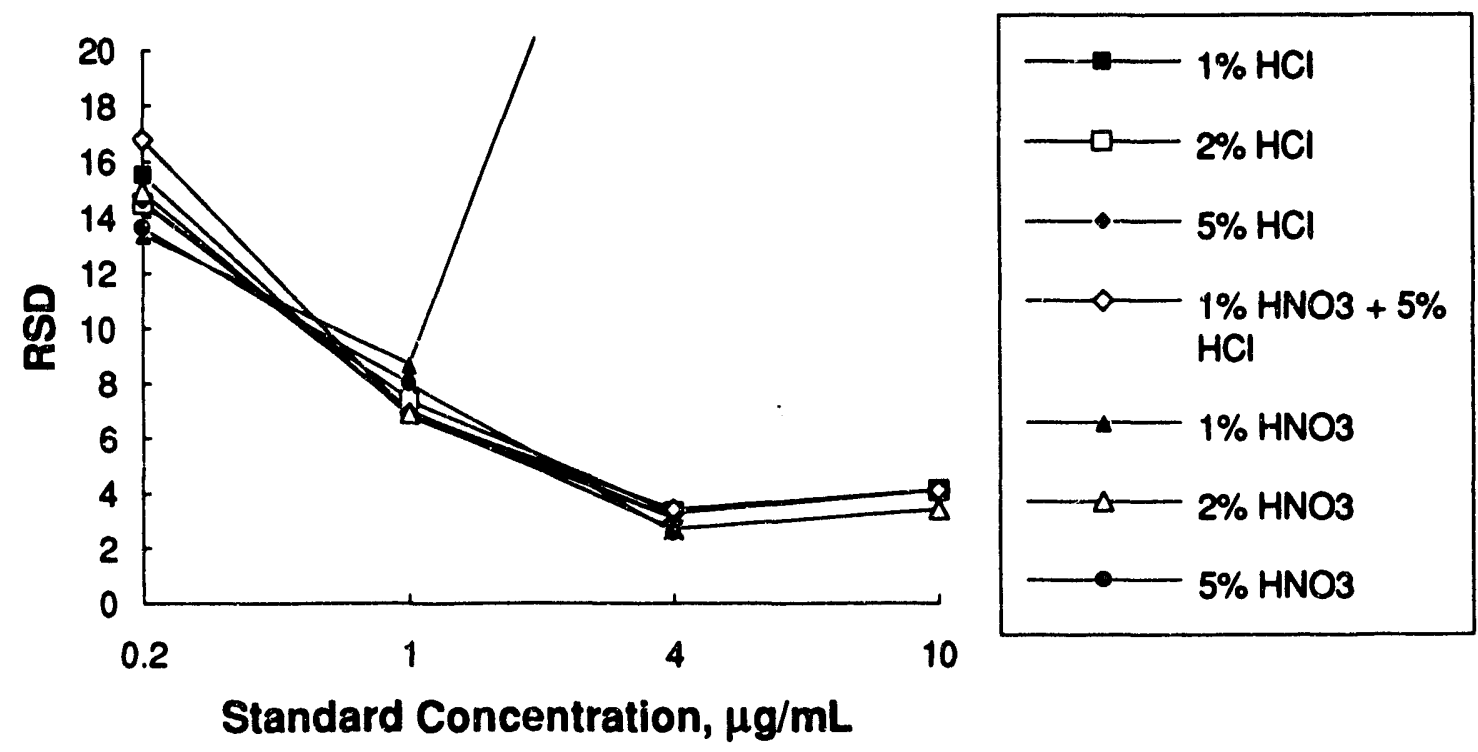

Standard Concentration, $\mu \mathrm{g} / \mathrm{mL}$ 
Distribution for ANL/ACL-92/3

Internal:

1. Ahmad

O. O. Ajayi

I. Ambats

D. V. Applegate

J. G. Asbury

R. W. Atcher

M. D. Atella

S. W. Ballou

A. Bandopadhyaya

R. W. Bane

D. A. Bass

J. K. Bates

J. E. Battles

C. A. Bebrich

N. J. Beskid

M. H. Bhattacharyya

S. K. Bhattacharyya

N. Bhatti

M. Blander

D. H. Bomkamp

A. S. Boparai

S. S. Borys

D. L. Bowers

B. S. Brown

F. A. Cafasso

S. E. Carpenter

Y. I. Chang

M. Clapper-Gowdy

R. B. Clare

S. M. Clark

J. H. Cleland

J. T. Collins

H. W. Conner

J. S. Crain

E. J. Croke

J. C. Cunnane

L. W. Deitrich

J. C. Demirgian

C. B. Dennis

M. H. Derbidge

D. R. Diercks
M. L. Dietz

J. D. Ditmars

H. Drucker

F. J. Dudek

B. D. Dunlap

A. J. Livorak

W. L. Ebert

A. G. Engelkemeir

M. D. Erickson

A. M. Essling

W. D. Fairman

I. M. Fox

F. Y. Fradin

N. W. Golchert

A. J. Goldman

H. T. Goodspeed

D. G. Graczyk

D. W. Green

D. M. Gruen

W. H. Gunther

J. E. Harmon

W. Harrison

D. A. Haugen

R. R. Heinrich

J. E. Helt

W. F. Henning

J. E. Herceg

R. L. Herriford

I. Hlohowskyj

E. P. Horwitz

H.-S. Huang

E. Huberman

D. R. Huff (10)

E. A. Huff (10)

E. Y. Hwang

M. J. Janik

K. J. Jensen

D. O. Johnson

P. L. Johnson

S. N. Kakar

?.. F. Kassner
S. D. Kent

C. E. Klotz

A. J. Kras

A. R. Krauss

J. R. Krsul

M. Lachman

L. L. Lamoureux

D. Larsen

S. L. Lawrence

K. H. Leong

L. G. LeSage

M. A. Lewis

P. C. Lindahl

M. J. Lineberry

C. D. Livengood

C. D. O. Loureiro

J. F. Marchaterre

F. Markun

V. A. Maroni

J. J. Marr

F. J. Martino

J. R. McCreary

H. F. McFarlane

C. A. Melendres

V. A. Mendez (10)

D. E. Moncton

L. R. Morss

T. P. Mulcahey

K. M. Myles

H. W. Myron

Z. Nagy

B. W. Nashold

L. A. Neimark

P. A. Nelson

R. D. Nixon

J. W. O'Kelley

Y. Orechwa

K. J. Parish

J.-H. Park

D. C. Parzyck

T. L. Patton 


$\begin{array}{lll}\text { C. V. Pearson } & \text { D. L. Smith } & \text { R. E. Toohey } \\ \text { D. R. Pedersen } & \text { F. P. Smith } & \text { A. Travelli } \\ \text { M. J. Pellin } & \text { L. L. Smith } & \text { Y. Tsai } \\ \text { M. Petrick } & \text { R. K. Smither } & \text { J. P. Unik } \\ \text { K. C. Picel } & \text { C. T. Snyder } & \text { R. A. Valentin } \\ \text { D. S. Poa } & \text { R. W. Springer } & \text { G. F. Vandegrift } \\ \text { R. B. Poeppel } & \text { B. Srinivasan } & \text { R. Venkatadri } \\ \text { A. J. Policastro } & \text { R. E. Stajdohar } & \text { K. S. Vorres } \\ \text { Y. L. Qian } & \text { V. C. Stamoudis } & \text { D. C. Wade } \\ \text { A. C. Raptis } & \text { M. J. Steindler } & \text { L. C. Walters } \\ \text { E. G. Rauh } & \text { C. M. Stevens } & \text { D. W. Warren } \\ \text { D. M. Ray } & \text { L. M. Stock } & \text { D. P. Weber } \\ \text { G. T. Reedy } & \text { W. E. Streets } & \text { R. W. Weeks } \\ \text { C. A. Reilly } & \text { K. Sugano } & \text { M. L. Wesely } \\ \text { M. J. Robinet } & \text { T. G. Surles } & \text { J. M. Williams } \\ \text { B. J. Roop } & \text { W. M. Swift } & \text { R. E. Winans } \\ \text { L. E. Ross } & \text { T. A. Taiwo } & \text { R. D. Wolson } \\ \text { C. S. Sabau } & \text { B. S. Tani } & \text { J. L. Woodring } \\ \text { N. A. Sacco-Gibson } & \text { J. D. Taylor } & \text { J. J. Wray } \\ \text { N. F. Sather } & \text { L. B. TenKate } & \text { R. A. Wynveen } \\ \text { W. W. Schertz } & \text { T. TenKate } & \text { J. S. Yaeger } \\ \text { A. Schriesheim } & \text { R. J. Teunis } & \text { R. K. Yoo } \\ \text { W. J. Shack } & \text { C. E. Till } & \text { ANL Patent Dept. } \\ \text { G. K. Shenoy } & \text { D. Tomasko } & \text { ANL Contract File } \\ \text { J. G. Sleeth } & \text { Z. Tomczuk } & \text { TIS Files (3) } \\ \text { D. L. Smith } & & \end{array}$

\section{External:}

DOE-OSTI (2)

ANL Library (2)

Manager, Chicago Operations Office, DOE

T. A. Baillieul, DOE-CH

J. C. Haugen, DOE-CH

A. L. Taboas, DOE-CH-AAO

Chemical Technology Division Review Committee Members:

S. Baron, Brookhaven National Laboratory, Upton, NY

D. L. Douglas, Consultant, Bloomington, MN

N. Jarrett, Noel Jarrett Associates, Lower Burrell, PA

J. G. Kay, Drexel University, Philadelphia, PA

J. Stringer, Electric Power Research Institute, Palo Alto, CA

J. B. Wagner, Arizona State University, Tempe, AZ

R. G. Wymer, Oak Ridge National Laboratory, Oak Ridge, TN

A. Alford-Stevens, U.S. Environ. Protection Agency, Cincinnati, OH

T. Beasley, U. S. Environmental Measurements Lab., New York, NY 
J. Bennett, EG\&G Idaho, Inc., Idaho Falls, ID

R. E. Berkeley, U.S. Environ. Protection Agency, Research Triangle Park, NC

C. D. Bingham, New Brunswick Laboratory, Argonne, IL

D. Bogen, USDOE, New York, NY

N. F. Christopher, Martin Marietta Energy Systems, Piketon, $\mathrm{OH}$

G. Clark, Reynolds Electric \& Engineering, Las Vegas, NV

C. E. Coffey, Westinghouse Savannah River Co., Aiken, SC

P. T. Cunningham, Los Alamos National Laboratory, Los Alamos, NM

J. L. Daniel, Battelle Pacific Northwest Laboratory, Richland, WA

H. J. Dewey, Los Alamos National Laboratory, Los Alamos, NM

D. A. Dodd, Westinghouse Hanford Co., Richland, WA

J. G. Donnon, Savannah River Plant, Aiken, SC

J. G. Dorsey, Martin Marietta Energy Systers, Oak Ridge, TN

L. P. Duffy, USDOE, Environ. Restoration \& W ute Manage., Washington, DC

P. A. Duhamel, USDOE, Health and Environmental Research, Germantown, MD

C. Elly, U. S. Environmental Protection Agency, Chicago, IL

D. J. Fauth, Analytical Lab West Valley Nuclear Services, West Valley, NY

C. Fellers, Mound Laboratory, Miamisburg, OH

R. B. Fitts, Oak Ridge National Laboratory, Oak Ridge, TN

C. W. Frank, USDOE, Office of Technology Development, Washington, DC

V. Gill, Westinghouse, Cincinnati, $\mathrm{OH}$

J. Goldstein, USDOE, Health and Environmental Research, Germantown, MD

T. C. Greengard, Rocky Flats Plant, Golden, CO

J. Harness, USDOE, Morgantown Energy Technology Center, Morgantown, WV

D. L. Herman, Westinghouse Materials Company of Ohio, Cincinnati, OH

D. Hunter, Rockwell International, Golden, CO

W. R. Jacobsen, Westinghouse Savannah River Co., A.iken, SC

W. Killian, Ferris State University, Big Rapids, MI

P. Krey, USDOE, Environmental Measurements Labs, New York, NY

W. R. Laing, Oak Ridge National Laboratory, Oak Ridge, TN

J. M. Latkovich, Battelle Pacific Northwest Laboratory, Richland, WA

R. G. Lewis, U.S. Environ. Protection Agency, Research Triangle Park, NC

L. C. Lewis, Westinghouse Idaho Nuclear Company, Idaho Falls, ID

D. Lillian, USDOE, Office of Technology Development, Washington, DC

R. M. Lugar, EG\&G Idaho, Inc., Idaho Falls, ID

C. Marcelo, New Brunswick Laboratory, Argonne, IL

W. A. McClenny, U.S. Environ. Protection Agency, Research Triangle Park, NC

S. Messenger, Morton Arboretum, Lisle, IL

R. W. Morrow, Martin Marietta Energy Sysems, Oak Ridge, TN

J. D. Mulik, U.S. Environ. Protection Agency, Research Triangle Park, NC

R. Norman, Gas Research Institute, Chicago, IL

R. Ohlinger, Westinghouse Materials Company of Ohio, Cincinnati, $\mathrm{OH}$

R. D. Oldham, New Brunswick Laboratory, Argonne, IL

J. Phillips, Los Alamos National Laboratory, Los Alamos, NM

J. D. Pleil, U.S. Environ. Protection Agency, Research Triangle Park, NC

F. Podosek, Washington University, St. Louis, MO 
J. W. Pyper, Lawrence Livermore National Laboratory, Livermore, CA

J. M. Ramirez, Allied-Signal, Inc., Kansas City, MO

C. Ross, U.S. Environmental Protection Agency, Chicago, IL

R. Scott, USDOE, Environmental Quality Assurance and Quality Control, Washington, DC

J. Q. Searcy, Sandia National Laboratories, Albuquerque, NM

W. D. Shults, Oak Ridge National Laboratory, Oak Ridge, TN

J. Smith, University of Chicago, Chicago, IL

J. R. Stetter, Transducer Research, Inc., Palos Hills, IL

F. D. Stevenson, USDOE, Basic Energy Sciences, Germantown, MD

C. Stroup, Westinghouse Hanford Company, Richland, WA

N. Trahey, National Institute of Standards and Technology, Gaithersburg, MD

R. Villarreal, Los Alamos National Laboratory, Los Alamos, NM

H. A. Vincent, U.S. Environmental Protection Agency, Las Vegas, NV

W. M. Walsh, Health Research Institute, Naperville, IL

W. C. Weimer, Battelle Pacific Northwest Laboratory, Richland, WA

R. P. Whitfield, USDOE, Environmental Restoration, Washington, DC

C. G. Whitworth, Jr., MSE, Inc., Butte, MT

R. J. Wingender, Gurnee, IL

P. D. Wooldridge, Paducah Gaseous Diffusion Plant, Paducah, KY

J. Zarret, EG\&G Rocky Flats Plant, Golden, CO 

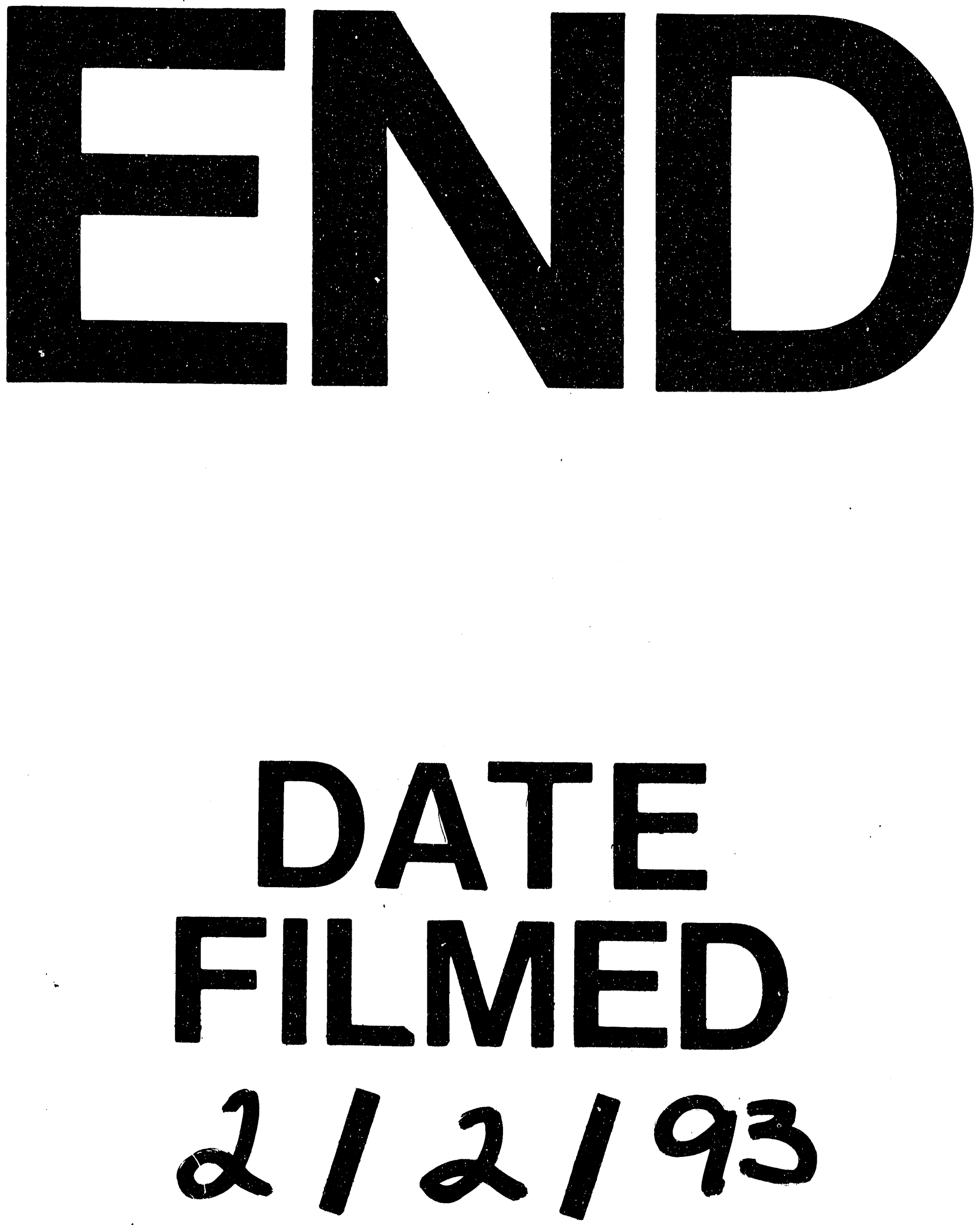
